\title{
DIGITALCOMMONS
}

@WAYNESTATE -

Wayne State University

$11-1-2010$

\section{Secessions, Coups, and the International Rule of Law: Assessing the Decline of the Effective Control Doctrine}

Brad R. Roth

Wayne State University, brad.roth@wayne.edu

\section{Recommended Citation}

Brad R. Roth, Secessions, Coups, and the International Rule of Law: Assessing the Decline of the Effective Control Doctrine, 11 Melb. J. Int'1. L. 393 (2010).

Available at: https://digitalcommons.wayne.edu/lawfrp/242 


\title{
SECESSIONS, COUPS AND THE INTERNATIONAL RULE OF LAW: ASSESSING THE DECLINE OF THE EFFECTIVE CONTROL DOCTRINE
}

\begin{abstract}
BRAD R ROTH *
Attempted secessions (for example, Kosovo and Somaliland) and coups d'état (for example, Madagascar and Honduras in 2009) prompt contestation over whether or not legal status is to be conferred on local exercises of de facto authority. International legal standing has traditionally been established by victory in a trial by ordeal: a region initially integral to an existing state successfully establishes itself as an independent sovereign unit only where its secession movement creates - usually by decisive victory in an armed struggle - facts on the ground that appear irreversible; an insurgent faction successfully establishes itself as a government where it overthrows an existing constitutional structure and secures - even if at bayonet-point - widespread popular acquiescence. Insofar as it is perceived as little more than an imprimatur for 'might makes right' at the local level, this 'effective control doctrine' is manifestly offensive to a rule-of-law sensibility. Notwithstanding the international order's disposition to defer to the outcome of internal conflicts, alternative solutions are available where a state manifestly fails to embody the self-determination of the entirety of the territorial population, or where a government manifestly fails to represent the political community that the state encompasses. These alternative solutions, however, far from generating new generally applicable doctrines, tend ineluctably to have an ad hoc character.
\end{abstract}

\section{CONTENTS}

I Introduction. 394

II Effective Control and the Assessment of Secession Questions 396

A 'Recognition' and International Legal Status: Constitutive and Declaratory Approaches

B Effectivity as an Aspect of the Traditional Criteria of Statehood.............. 398

C Self-Determination of Peoples in Non-Colonial Contexts ........................ 404

D Non-Consensual Dissolution of Federal States: The Badinter Improvisation.

E Kosovo and Beyond: The Inevitability of Ad Hoc Responses to Secession Crises

III Effective Control and the International Status of Coup Regimes.

A Popular Sovereignty, Ideological Pluralism, and the Effective Control Doctrine

B Toward a Doctrine of Governmental Illegitimacy in International Law: The Haiti and Sierra Leone Cases

C The Anti-Coup Proclamations of Regional Organisations

D The New Wave of Rejection of Coup Regimes: Honduras and Madagascar

IV Conclusion: The Decline of the Effective Control Doctrine and the Absence of a Coherent Substitute

* JD (Harvard); LLM (Columbia); PhD (Berkeley). Associate Professor of Political Science and Law, Wayne State University. The author wishes to thank Jean d'Aspremont for his helpful comments. 


\section{INTRODUCTION}

Although 'recognition' is frequently discussed as a political or diplomatic rather than a legal matter, no task is more fundamental to the international rule of law than that of identifying both the primary units of the global order and the institutions that have standing to act in the name of those units. International law acknowledges 'states' as bearers of a distinctive package of rights, obligations, powers and immunities (that is, 'sovereignty'), and attributes to each state a 'government' with the legal capacity (for the time being) to assert rights, incur obligations, exercise powers, and confer immunities on the state's behalf. ${ }^{1}$ Where contestation arises over whether an entity has the legal properties of a state or whether a particular governmental apparatus acts validly in the state's name, legal relationships of all kinds are called into question. ${ }^{2}$ Legal doctrines are thus needed to govem international conferral of legal status on local exercises of de facto authority, whether carried out in the name of new sovereign units (for example, Kosovo and Somaliland) or of new leaderships asserting rule over existing sovereign units (for example, new regimes coming to power by force in Madagascar and Honduras in 2009).

The international legal order's repudiation of 'might makes right' in relations among states masks a critical component of that order's traditional doctrines governing what is cognisable as an exercise of state authority: an emphasis on present or past patterns of 'effective control'. Although the doctrinal schemes for recognising states and governments are distinct and are each complex, a traditional common thread is the role played by 'effective control through internal processes' - processes that may be marked by the very violence and coercion that the international order disdains to dignify in interstate relations. International legal standing has traditionally been established by victory in a trial by ordeal: a region initially integral to an existing state successfully establishes itself as an independent sovereign unit only where its secession movement creates - usually by decisive victory in an armed struggle - facts on the ground that appear irreversible; an insurgent faction successfully establishes itself as a government where it overthrows an existing constitutional structure and secures - even if at bayonet-point - widespread popular acquiescence. The international order's attribution of sovereign independence to established territorial political communities thereby has traditionally entailed (to put it most bluntly) the right of each to fight its civil war in peace and to be ruled by its own thugs. Insofar as it is perceived as little more than an imprimatur for 'might makes right' at the local level, this 'effective control doctrine' is manifestly offensive to a rule of law sensibility.

1 The legal framework for the latter attribution is the theme of the author's 1999 book. See Brad R Roth, Governmental Illegitimacy in International Law (Oxford University Press, 1999).

2 Of greatest potential significance in this context is the authority to invite foreign military forces to play a role in bolstering a particular system of public order against challenges by its rivals. See, eg, Gerhard Hafner, 'Present Problems of the Use of Force in International Law: D Sub-Group on Intervention by Invitation' (Report, Institut de Droit International, 25 July 2007) <www.idi-iil.org/idiF/annuaireF/10th_commission_d.pdf >; Louise Doswald-Beck, 'The Legal Validity of Military Intervention by Invitation of the Government' (1985) 56 British Year Book of International Law 189. 
It comes as no surprise, then, that so many present day commentators, theorists, jurists, and even diplomats view the effective control doctrine negatively, and resist its implications for contemporary recognition controversies. Where local impositions appear to defy popular will or the rule of law, there is a natural inclination, consistent with the moral principles articulated in international human rights instruments and other authoritative international pronouncements, to prefer more plausibly democratic or constitutional solutions to recognition contests. In the developments of the past two decades, there is a nexus between trends in the recognition of states and those in the recognition of governments: the international community's rejection of local efforts to maintain by force the territorial integrity of the Socialist Federal Republic of Yugoslavia ('SFRY'), in the face of clear majorities for independence within the constitutionally established territorial sub-units, is of a piece with the international community's newfound reluctance to recognise unconstitutional seizures of power from democratically elected authorities.

However, the effective control doctrine cannot be so easily jettisoned. The doctrine fills a void inherent in a decentralised legal order founded on arbitrarily-drawn territorial boundaries and beset by continuing clashes of both interests and values. While a rigid application of traditional premises may produce genuinely perverse results, a radical departure from those premises would open up questions that the international system has had good reason to keep closed, and would potentially invite the kind of unconstrained external intervention in internal affairs that the international law of peace and security seeks to preclude. Disparagement of the effective control doctrine is all too easy in the absence of a 'moral reading' of the doctrine, ${ }^{3}$ one that exposes the doctrine's role in effectuating the purposes and principles of the United Nations Charter system.

The effective control doctrine is best understood, not as an amoral or tactical concession to realpolitik, but as a means of reconciling two fundamental principles of the international order's relationship to domestic political authority: popular sovereignty and ideological pluralism. On the one hand, the United Nations Charter is notionally a compact, not among ruling apparatuses, but among territorially-based political communities; respect for existing states and governments in that framework is formally premised on the idea that these states manifest the self-determination of their whole populations without distinction, and that existing governmental structures (for the time being) authentically represent those states. On the other hand, the Charter and its official glosses "envisage the relations among States having different political, economic and social systems on the basis of coexistence among their various ideologies'; ${ }^{4}$ the

3 The legal philosopher Ronald Dworkin privileges an interpretation of law that 'all things considered, makes the community's legal record the best it can be from the point of view of political morality': Ronald Dworkin, Law's Empire (Harvard University Press, 1986) 411, an approach which Dworkin later termed a 'moral reading'.

4 See Military and Paramilitary Activities in and against Nicaragua (Nicaragua v United States) (Judgment) [1986] ICJ Rep 14, 133 ('Nicaragua'); see also Declaration on the Principles of International Law concerning Friendly Relations and Co-operation among States in Accordance with the Charter of the United Nations, GA Res 2625 (XXV) UN GAOR, $6^{\text {th }}$ Comm, $25^{\text {th }}$ sess, $1883^{\text {rd }}$ plen mtg, Agenda Item 85, UN Doc A/RES/2625 (XXV), annex (24 October 1970) ('Friendly Relations Declaration'). 
system's ideological pluralism, while not preclusive of efforts to promote human rights and democratic participation, has generally militated against any international effort to nullify the legal status of emanations from established and effective domestic authority. The effective control doctrine squares popular sovereignty with ideological pluralism by establishing a presumption - in many circumstances, an irrebuttable one - that enduring patterns of effective authority reflect underlying realities consistent with the Charter's idealisation of existing states and governments.

In the past two decades, the international order's ideological pluralism has narrowed, and numerous events have highlighted, for observers across the spectrum of principled world views, the unreasonableness of an irrebuttable presumption that effective control manifests popular will. Given these developments, the effective control doctrine has inevitably begun to fray.

Nonetheless, facile invocations of democratic or constitutionalist values do not provide a firm foundation for substitute approaches to the recognition of states and governments. Because democracy and constitutionalism are themselves open-textured and contested concepts, their application to recognition questions has the potential to yield equally arbitrary, but far less stable and predictable, outcomes. Despite occasional exceptions and bursts of exuberant rhetoric about popular will and the rule of law, the effective control doctrine continues to play a crucial role in setting the international system's default position on ascriptions of the statuses of 'state' and 'government'. Consequently, the international community's resolutions of the pressing recognition questions of the day, from the 2008 Kosovar Unilateral Declaration of Independence to the 2009 Honduran coup d'état, are destined to have an ad hoc quality that will leave observers (and, of course, many partisans) unsatisfied.

\section{EFFECTIVE CONTROL AND THE ASSESSMENT OF SECESSION QUESTIONS}

\section{A 'Recognition' and International Legal Status: Constitutive and Declaratory Approaches}

Although the conferral of international legal status on states and governments is typically discussed in the same breath as 'recognition', the precise relationship between the entity's legal status and other states' recognition of the entity remains unresolved in international law. Most authorities repeat the orthodoxy that the entity's legal status is an objective matter and that the entity's reception by other states is merely 'declaratory', rather than 'constitutive', of that status, ${ }^{5}$ but the reality is more complicated than such assertions suggest.

One source of confusion is that 'recognition' in this context is ordinarily identified with overt gestures - such as declarations of recognition, the opening of full diplomatic relations, the issuance of certificates of recognition addressed

5 See, eg, Maurizio Ragazzi, 'Conference on Yugoslavia Arbitration Commission, Opinions on Questions Arising from the Dissolution of Yugoslavia' (1992) 31 ILM 1488, 1492. 
to internal courts, or the admission of the entity (or, in the case of a putative government, the credentialing of its representatives) to an international organisation for which statehood is a requirement - that are, even though sufficient indications, not necessary concomitants of a legal consciousness that the entity bears a particular status. A foreign state may acknowledge (or take cognisance of) the entity's legal status, even while being unwilling to make what looks like a political statement in the entity's favour. An aggregation of such acknowledgments, reflecting the opinio juris of the greater part of the international community, is much more plausibly constitutive of statehood than the orthodox view concedes. ${ }^{6}$

Even those who deny that recognition is legally constitutive of status tend to concede its indirect legal relevance. ${ }^{7}$ Without question, while an elaborate body of legal doctrine purports to govern status determinations, whether a territorial entity actually experiences the legal benefits of statehood turns on whether other states treat the entity as having statehood's legal attributes. As with the old riddle, "If a tree falls in a forest and no one is there to hear it, does it make a sound?' there may be little practical consequence to an objective legal status that

6 According to the most celebrated publicist of recognition practice, Sir Hersch Lauterpacht (writing in 1947):

The view of recognition which has here been presented as approximating most closely to the practice of States and to a working juridical principle is: (a) that recognition consists in the application of a rule of international law by way of ascertaining the existence of the requisite conditions of statehood; and (b) that the fulfilment of that function in the affirmative sense - and nothing else - brings into being the plenitude of the normal rights and duties which international law attaches to statehood.

Hersch Lauterpacht, Recognition in International Law (Cambridge University Press, 1947), 73. Thus, members of the international community (either separately or in coordination) have a duty to recognise as states those entities that qualify for the status under applicable legal criteria, but it is only their implementation of this duty that brings statehood into being. Lauterpacht expressed the point as follows:

[The] full international personality of rising communities ... cannot be automatic ... [A]s its ascertainment requires the prior determination of fact and law, there must be someone to perform that task. In the absence of a preferable solution, such as the setting up of an impartial international organ to perform that function, the latter must be fulfilled by States already existing. The valid objection is not against the fact of their discharging it, but against their carrying it out as a matter of arbitrary policy as distinguished from legal duty.

7 James Crawford, for example, maintains that "[a]n entity is not a State because it is recognized; it is recognized because it is a State': James Crawford, The Creation of States in International Law (Oxford University Press, $2^{\text {nd }}$ ed, 2006) 93. He nonetheless maintains at 27 (citations omitted) that recognition can

have important legal and political effects. Recognition is an institution of State practice that can resolve uncertainties as to status and allow for new situations to be regularized. That an entity is recognized as a State is evidence of its status; where recognition is general, it may be practically conclusive. States, in the forum of the United Nations or elsewhere, may make declarations as to status or 'recognize' entities the status of which is doubtful; depending on the degree of unanimity and other factors this may be evidence of a compelling kind.

However, since the presence or absence of objective criteria can be independently ascertained (and indeed, far more accurately so in the absence of the distortions introduced by diplomacy), it makes no sense to speak of recognition as providing 'evidence' - let alone 'practically conclusive' evidence - for an entity's fulfilment of such criteria. What recognition establishes is not some empirical truth about the entity, but rather the position that states and intergovernmental organisations take toward the entity. 
the relevant community fails to acknowledge. It remains to be asked only whether the position adopted by states, collectively or aggregatively, can be said to govern the entity's entitlements, ${ }^{8}$ or whether, by contrast, the entitlements are so fully objective that where the bulk of the international community is seen to misapply the fixed legal criteria, states treating the entity in accordance with that collective misapplication can be said thereby to breach their legal obligations. ${ }^{9}$

Either view is conceptually possible, but as a practical matter, the latter view seems implausible, for at least two reasons. First, it assumes away the international community's need for authoritative judgment as to whether particular doctrinally relevant events will be permitted to affect an entity's legal status; the facts on the ground can hardly be said to speak for themselves, and yet remarkable coordination has prevailed in this area of state practice, as evidenced by the paucity of genuine recognition controversies in contrast to the plethora of intense crises of local authority. Second, the collective opinio juris in application to the case at hand, if clearly manifested and essentially uniform, can be construed as a refinement of accepted legal doctrine and thus as itself a lawmaking phenomenon.

Even if collective legal acknowledgment of an entity's status is ultimately constitutive, such acknowledgment is composed of the individual recognition practices of foreign ministries and intergovernmental organisations, which are bound to determine those practices in light of international law, with an error in either direction potentially entailing a breach of legal obligation. Moreover, where the international reaction is split (for example, in respect of Kosovo) or where it is difficult to discern whether prevailing state practice reflects opinio juris or is purely political in character (for example, in respect of Taiwan), ${ }^{10}$ there is no substitute for an independent determination of whether the legal criteria of statehood have been objectively fulfilled.

\section{B Effectivity as an Aspect of the Traditional Criteria of Statehood}

The characteristics of statehood are routinely said to be those four listed in art 1 of the 1933 Montevideo Convention on Rights and Duties of States: '(a) a permanent population; (b) a defined territory; (c) a government; (d) the capacity

8 Crawford rejects this reasoning on the ground that in international law generally, neither individual nor collective determinations of states have definitive legal effect: ibid 20 . But the notorious puzzle of the role of opinio juris in customary law formation is precisely this: that a legal duty is constituted, in part, by the widespread state perception of the existence of the duty. The anomaly seems no worse in the application of norms than in their formation.

9 That this is not an entirely moot question is demonstrated in Robert D Sloane, 'The Changing Face of Recognition in International Law: A Case Study of Tibet' (2002) 16 Emory International Law Review 107: Sloane attributes Tibet's pre-1950 lack of international recognition wholly to the combination of Tibet's peculiarly unassertive leadership and the crassly political decisions of the very few interacting states. He contends that China's control of the territory to this day represents an illegal occupation of a Tibetan state that maintains an objective legal existence: at 135-51.

10 See Brad R Roth, 'The Entity That Dare Not Speak Its Name: Unrecognized Taiwan as a Right-Bearer in the International Legal Order' (2009) 4 East Asia Law Review 91; Brad R Roth, 'Taiwan's Nation-Building and Beijing's Anti-Secession Law: An Intemational Law Perspective' in Chen Chi-sen et al (eds), Sovereignty, Constitution, and the Future of Taiwan (Taiwan Law Society, 2006) 1. 
to enter into relations with other states'. ${ }^{11}$ This enumeration reflects that Convention's purpose of placing respect for the rights of states on a non-discretionary and ideologically neutral footing. The Montevideo Convention sought to predicate the entity's status, not on political predilection or moral entitlement (as to which competing interests and values promised to generate endless controversy), but on whether the entity constituted an objective political unit, not subject to the law of another state, that had to be reckoned with on the basis of international law.

Article 3 of the Montevideo Convention thus affirms that " $t \mathrm{t}]$ he political existence of the state is independent of recognition by the other states', and ascribes to the state '[e]ven before recognition ... the right to defend its integrity and independence, to provide for its conservation and prosperity, and consequently to organise itself as it sees fit, to legislate upon its interests, administer its services, and to define the jurisdiction and competence of its courts'. The reference in art 1 to 'the capacity to enter into relations with other states' thus appears to have been intended, not as conditioning statehood on the entity's reception by other states, but as excluding entities whose international relations were confessedly subordinate to another state - that is, units of federal states (for example, Michigan, Tasmania) and territories that have full internal self-governance but are dependent in external affairs (for example, 'associated statehood' arrangements, such as the relationship of the Cook Islands to New Zealand). ${ }^{12}$

As independent criteria for statehood, 'permanent population' and 'defined territory' merely beg the question, since virtually all statehood claims, whether or not accepted in the international legal order, characteristically include sufficiently precise claims on behalf of a permanent population to a defined territory. What matters in the Montevideo Convention context is that the 'permanent population' and 'defined territory' be united by some common and distinguishing pattern of effective governance. Thus, if taken as the legal standard for international personality, the Montevideo criteria would confer sovereign rights, obligations, powers, and immunities on any territorially-coherent political community found under the long-term effective control of an independent government.

However, such a standard falls far short of capturing the essence of traditional recognition practice. Many states have continued to be recognised as undivided political units notwithstanding the failure of the central government to maintain effective control over substantial parts of the national territory. Indeed, in some cases, new states were recognised without a central government ever having established effective control throughout the territory. ${ }^{13}$ A state is more plausibly

11 Montevideo Convention on Rights and Duties of States, opened for signature 26 December 1933, 165 LNTS 20 (entered into force 26 December 1934) ('Montevideo Convention').

12 A state 'has competence, within its own constitutional system, to conduct international relations ... as well as the political, technical, and financial capabilities to do so': American Law Institute, Restatement (Third) of the Foreign Relations Law of the United States (1987) $\S 201 \mathrm{cmt}$ (e), quoted in Christopher J Carolan, "The "Republic of Taiwan": A Legal-Historical Justification for a Taiwanese Declaration of Independence' (2000) $75 \mathrm{New}$ York University Law Review 429, 455 n 167.

13 This has been true in, for example, the contexts of decolonisation (for example, Democratic Republic of the Congo in 1960 and Angola in 1975) and state dissolution (for example, Croatia and Bosnia-Herzegovina in 1992). 
defined, in conformity with recognition practice, not as a territorially-based political community that is effectively self-governing, but as a territorially-based political community that existing states collectively decide ought to be self-governing, whether based on existing, remembered, or foreseen patterns of governance within it.

Insofar as the international community's deviations from the effective control requirement can be attributed to a doctrinal logic, three countervailing traditional doctrines can be identified: (1) the Stimson Doctrine; (2) the rule against 'premature' recognition; and (3) the principle of self-determination of peoples as applied to the project of decolonisation.

The Stimson Doctrine, so named for the early-1930s efforts of the United States Secretary of State to mobilise opposition to the recognition of Manchukuo, holds that a foreign state's unlawful intervention - in that case, Japan's invasion of the northern Chinese province of Manchuria in violation of the 1928 Kellogg-Briand Pact of Paris - cannot be allowed to yield a successful secession. ${ }^{14}$ The Stimson Doctrine remains relevant to this day, and has precluded almost all states from recognising breakaway regions of Georgia (Abkhazia and South Ossetia, unlawfully sponsored by Russia), ${ }^{15}$ Moldova (Transnistria, unlawfully sponsored by Russia), ${ }^{16}$ Azerbaijan (Nagorno-Karabakh, unlawfully sponsored by Armenia), ${ }^{17}$ and Cyprus (the Turkish Republic of Northern Cyprus, unlawfully sponsored by Turkey). ${ }^{18}$

Unlike the Stimson Doctrine, the rule against premature recognition operates even in the absence of unlawful foreign assistance to a secession movement. Rather, it asserts that premature recognition itself constitutes unlawful intervention in the internal affairs of the pre-existing state. ${ }^{19}$ The rule is premised on the state's sovereign right to use force within national boundaries to preserve

14 See, eg, Malcolm N Shaw, International Law (Cambridge University Press, $5^{\text {th }}$ ed, 2003), 390-1. See also Responsibility of States for Internationally Wrongful Acts, GA Res 56/83, UN GAOR, 56 ${ }^{\text {th }}$ sess, Agenda Item 162, UN Doc A/RES/56/83 (28 January 2002) annex, arts 40-1: 'No State shall recognize as lawful a situation created by' a 'gross or systematic failure by the responsible State to fulfil' a peremptory obligation, nor may a State 'render aid or assistance in maintaining that situation'; Legal Consequences of the Construction of a Wall in the Occupied Palestinian Territory (Advisory Opinion) [2004] ICJ Rep 36, 233 (Judge Kooijmans), noting that the obligation of non-recognition of unlawful situations applies to 'legal claims to territory'.

15 See, eg, Christopher J Borgen, 'The Language of Law and the Practice of Politics: Great Powers and the Rhetoric of Self-Determination in the Cases of Kosovo and South Ossetia' (2009) 10 Chicago Journal of International Law 1.

16 See, eg, Christopher J Borgen, 'Imagining Sovereignty, Managing Secession: The Legal Geography of Eurasia's "Frozen Conflicts"' (2007) 9 Oregon Review of International Law 477.

17 See SC Res 822, UN SCOR, $48^{\text {th }}$ sess, $3205^{\text {th }} \mathrm{mtg}$, UN Doc S/RES/822 (30 April 1993); SC Res 853 , UN SCOR, $48^{\text {th }}$ sess, $3259^{\text {th }} \mathrm{mtg}$, UN Doc S/RES/853 (29 July 1993); SC Res 874 , UN SCOR, $48^{\text {th }}$ sess, $3292^{\text {nd }} \mathrm{mtg}$, UN Doc S/RES/874 (14 October 1993); SC Res 884, UN SCOR, $48^{\text {th }}$ sess, $3313^{\text {th }} \mathrm{mtg}$, UN Doc S/RES/884 (12 November 1993) calling for the withdrawal of Armenian troops.

18 See SC Res 541, UN SCOR, 38 ${ }^{\text {th }}$ sess, $2500^{\text {th }} \mathrm{mtg}$, UN Doc S/RES/541 (18 November 1983) on the 'invalidity' of the Turkish Republic of Northern Cyprus's declaration of independence.

19 See, eg, Shaw, above n 14, 383. 
its territorial integrity, and its right against any interference with such efforts by a foreign state. ${ }^{20}$ The Brierly treatise explains the rule's contours as follows:

It is impossible to determine by fixed rules the moment at which other states may justly grant recognition of a new state; it can only be said that so long as a real struggle is proceeding, recognition is premature, whilst, on the other hand, mere persistence of the old state in a struggle that has obviously become hopeless is not a sufficient cause for withholding it. ${ }^{21}$

Lauterpacht went a bit further to say that 'the sovereignty of the mother country is a legally relevant factor so long as it not abundantly clear that the lawful government has lost all hope or abandoned all effort to reassert its dominion'.22

But in reality, the rule is even harsher in application. As Crawford points out:

Since 1945 no state which has been created by unilateral secession has been admitted to the United Nations against the declared wishes of the government of the predecessor state. By contrast there are many examples of failed attempts at unilateral secession, including cases where the seceding entity maintained de facto independence for some time. ${ }^{23}$

An example is the case of Eritrea, which achieved international recognition only after Ethiopia's formal relinquishment, despite far earlier establishment of the 'facts on the ground'. ${ }^{24}$ Even a clear-cut military victory by secessionist forces does not seem, in practice, to yield an international acknowledgment of independence until the original state concedes the point.

While the rule against premature recognition supplants 'effective control through internal processes' as the actual touchstone of status in cases of secessionary wars, it operates on the same essential logic, qualified only by a 'first in time' proviso. The 'prematurity' formulation implies that the boundaries of the 'internal' are independent of the boundaries of effective control, until and unless the latter somehow 'mature'. Sovereignty is 'earned' by effective struggle, with a very strong presumption in favour of the forces that earned it first. Not only are the borders between states, however much the result of past conquests, sanctified as of the inauguration of the current peace and security order, but the

20 Declaration on the Inadmissibility of Intervention and Interference in the Internal Affairs of States, GA Res $36 / 103$, UN GAOR, $36^{\text {th }}$ sess, $91^{\text {st }}$ plen $\mathrm{mtg}$, UN Doc A/RES/36/103 (9 December 1981), annex ('1981 Non-Intervention Declaration'), which passed 120:22:6 in the face of opposition of many Western liberal states, emphasised, inter alia, '[t]he duty of a State to refrain from the promotion, encouragement or support, direct or indirect, of rebellious or secessionist activities within other States, under any pretext whatsoever, or any action which seems to disrupt the unity or to undermine or subvert the political order of other States': Annex, art 2(f) (emphasis added). Similarly, the Friendly Relations Declaration, UN DOC A/RES/2625 (XXV), states that 'no State shall ... interfere in civil strife in another State': Preamble.

21 J L Brierly, The Law of Nations (Oxford University Press, $6^{\text {th }}$ ed, 1963) 138, quoted in David A Ijalaye, 'Was "Biafra" at Any Time a State in International Law?' (1971) 55 American Journal of International Law 551, 558.

22 Lauterpacht, above n 6, 46, quoted in Ijalaye, above n 21, 558.

23 James Crawford, 'State Practice and International Law in Relation to Secession' (1998) 69 The British Year Book of International Law 85, 92 (citations omitted); see also Crawford's summary of non-recognition practice at 116.

24 Ibid 106-7. 
territorial integrity of existing states is all but frozen, subject to modification only through an unambiguous outcome of a trial by ordeal.

The third countervailing doctrine concerns self-determination as applied to Non-Self-Governing and Trust Territories, which the UN Charter-based order regards as not integral to the states governing them. Chapters XI to XIII of the Charter gave imprimatur to Western powers' control over colonised territories, but predicated the legitimacy of that control on fiduciary responsibility rather than sovereign authority. By 1960 , that approach had given way to the demands for an end to colonialism in all of its forms.

Resolution 1514, issued without a dissenting vote, fatefully stated: 'All peoples have the right to self-determination; by virtue of that right they freely determine their political status and freely pursue their economic, social and cultural development'. ${ }^{25}$ However indeterminate the implications of this statement may be outside of the colonial realm, the consequences for Western European 'salt water colonialism' were concrete:

Immediate steps shall be taken, in Trust and Non-Self-Governing Territories or all other territories which have not yet attained independence, to transfer all powers to the peoples of those territories, without any conditions or reservations, in accordance with their freely expressed will and desire, without any distinction as to race, creed or colour, in order to enable them to enjoy complete independence and freedom. 26

The accompanying resolution, Resolution $1541^{27}$ though framed rather innocuously as an interpretation of an obscure obligation of colonial powers under Chapter XI of the Charter to 'transmit information' on 'economic, social, and educational conditions' in Non-Self-Governing Territories, in effect established (over the dissenting votes of only Portugal and South Africa) the criteria for specifying the territories, upon the populations of which the previous resolution had conferred an immediate right to 'freely determine their political status' by opting for sovereign independence. The category included any 'territory which is geographically separate and is distinct ethnically and/or culturally from the country administering it' and which is subject to 'administrative, political, juridical, economic, or historical' factors that

25 Declaration on the Granting of Independence to Colonial Countries and Peoples, GA Res 1514 (XV), UN GAOR, $15^{\text {th }}$ sess, $947^{\text {th }}$ plen mtg, UN Doc A/RES/1514 (XV) (14 December 1960) [2] ('Resolution 1514'). The Security Council reaffirmed the statement in SC Res 183, UN SCOR, $18^{\text {th }}$ sess, $1083^{\text {rd }} \mathrm{mtg}$, UN Doc S/5481 (11 December 1963) [4]. The same language is repeated in other declarations and instruments, and constitutes art $1(1)$ of both the International Covenant on Civil and Political Rights, opened for signature 16 December 1966, 999 UNTS 171 (entered into force 23 March 1976) ('ICCPR') and the International Covenant on Economic, Social and Cultural Rights, opened for signature 16 December 1966, 993 UNTS 3 (entered into force 3 November 1976) ('ICESCR').

26 Resolution 1514, UN Doc A/RES/1514 (XV) [5].

27 Principles Which Should Guide Members in Determining Whether or Not an Obligation Exists to Transmit the Information Called for under Article 73(e) of the Charter, GA Res 1541 (XV), UN GAOR, $4^{\text {th }}$ Comm, 948 ${ }^{\text {th }}$ plen mtg, UN Doc A/RES/1541 (XV) (15 December 1960 ('Resolution 1541'). 
'arbitrarily place it in a position or status of subordination' ${ }^{28}$ In purporting to interpret Chapter XI, Resolution 1541 noted that the chapter's authors 'had in mind' its application to 'territories which were then known to be of the colonial type'. ${ }^{29}$ Whether this articulation of principle can so easily be cabined is another matter, but the immediate applications were unambiguous. ${ }^{30}$

Equally unambiguous was the authoritative position on the boundaries of territorial units emerging from colonial status: "Any attempt aimed at the partial or total disruption of the national unity and the territorial integrity of a country is incompatible with the purposes and principles of the Charter of the United Nations' ${ }^{31}$ It was no accident that the most vociferous advocates of the right to self-determination, the new states emerging from decolonisation, were also the most determined to limit its application. The new states perceived most keenly their vulnerability to territorial fragmentation and to threats to their political independence posed by (real and imagined) neo-colonialist penetration. Thus, even though (and indeed, partly because) the newly independent units' central authorities had not fully established effective control throughout all parts of the allocated territories, ${ }^{32}$ the dice were heavily loaded against secessionist factions (beginning with Katangese insurgents in the Democratic Republic of the Congo). ${ }^{33}$

The strength of the presumption in favour of territorial integrity vis-à-vis internal contestants was driven by much the same concern as the separate and more overtly absolute insistence on the inviolability of post-decolonisation

28 Ibid annex Principle VI: 'A Non-Self-Governing Territory can be said to have reached a full measure of self-government by: (a) Emergence as a sovereign independent State; (b) Free association with an independent State; or (c) Integration with an independent State.' The first option is framed not only as an absolute right, but as the presumptive outcome, whereas the latter two choices are laden with requisites calculated to assure that they result from a genuine exercise of popular will. See Principles II, VI, VII, VIII, IX.

29 Ibid annex Principle I.

30 Despite being mere General Assembly resolutions, Resolution 1514 and Resolution 1541 quickly attained the status of binding international law in the eyes of UN organs, notwithstanding 'persistent objection' from Portugal and South Africa: see SC Res 180, UN SCOR, $18^{\text {th }}$ sess, $1049^{\text {th }} \mathrm{mtg}$, UN Doc S/5380 (31 July 1963); SC Res 183, UN SCOR, $18^{\text {th }}$ sess, $1083^{\text {rd }} \mathrm{mtg}$, UN Doc S/5481 (11 December 1963). The Security Council 'deprecat[ed]' Portugal's intransigence in refusing to implement the General Assembly resolutions, noted that such action was incompatible with Portugal's obligations under the UN Charter, and expressly confirmed Resolution 1514: [1], [3]; Legal Consequences for States of the Continued Presence of South Africa in Namibia (South West Africa) notwithstanding Security Council Resolution 276 (Advisory Opinion) [1971] ICJ Rep 16, 31-2: 'A further important stage in [the development of international law subsequent to the Charter] was the Declaration on the Granting of Independence to Colonial Countries and Peoples'; Western Sahara (Advisory Opinion) [1975] ICJ Rep 12, 31-3.

31 Resolution 1514, UN Doc A/RES/1514 (XV) [6].

32 Many emergent states were, as Robert Jackson puts it, mere 'quasi-states': their statehood was 'primarily juridical', for while they 'have been internationally enfranchised and possess the same external rights and responsibilities as all other sovereign states', they were 'deficient in the political will, institutional authority, and organized power to protect human rights or provide socioeconomic welfare': Robert H Jackson, Quasi-States: Sovereignty, International Relations, and the Third World (Cambridge University Press, 1990) 21.

33 See Rene Lemarchand, 'The Limits of Self-Determination: The Case of the Katanga Secession' (1962) 56 American Political Science Review 404; M Rafiqul Islam, 'Secessionist Self-Determination: Some Lessons from Katanga, Biafra and Bangladesh' (1985) 22 Journal of Peace Research 211. 
boundaries vis-à-vis external contestants, that is, the principle of uti possidetis. As the International Court of Justice explained in 1986:

Uti possidetis, as a principle which upgraded former administrative delimitations, established during the colonial period, to international frontiers, is ... a principle of a general kind which is logically connected with this form of decolonization wherever it occurs.

The territorial boundaries which have to be respected may also derive from international frontiers which previously divided a colony of one State from a colony of another, or indeed a colonial territory from the territory of an independent State, or one which was under protectorate, but had retained its international personality. There is no doubt that the obligation to respect pre-existing international frontiers in the event of a State succession derives from a general rule of international law, whether or not the rule is expressed in the formula uti possidetis. ...

At first sight this principle conflicts outright with another one, the right of peoples to self-determination. In fact, however, the maintenance of the territorial status quo in Africa is often seen as the wisest course, to preserve what has been achieved by peoples who have struggled for their independence, and to avoid a disruption which would deprive the continent of the gains achieved by much sacrifice. The essential requirement of stability in order to survive, to develop and gradually to consolidate their independence in all fields, has induced African States judiciously to consent to the respecting of colonial frontiers, and to take account of it in the interpretation of the principle of self-determination of peoples. ${ }^{34}$

Thus, all of the traditional rules place a premium on territorial integrity. Even where these rules are at odds with actual effectivity, they favour the legal prerogative of existing states' central authorities to re-establish by forcible means the effective control that local resistance has compromised. Unless secessionist forces can, unaided by inadmissible foreign intervention, prevail upon an existing state to relinquish the territory in question, the traditional rules leave little prospect - except in the case of the most unambiguous victory in a civil war (and even then, it seems, only notionally) - for a new state to emerge at the expense of an existing state's territorial integrity.

\section{Self-Determination of Peoples in Non-Colonial Contexts}

Although the anti-colonial movement was greatly concerned with non-fragmentation, it could not be content to limit the applicability of self-determination to the liberation of dependent territories, if for no other reason than that vestiges of colonialism might be preserved within independent entities. Southern Rhodesia's 1965 Unilateral Declaration of Independence, for example, separated the territory from the colonial power, but did not change the reality of colonial settler domination (and was, indeed, an effort to frustrate substantive decolonisation); similarly, apartheid in South Africa, though colonialist in nature, was the policy of a sovereign state.

34 Frontier Dispute (Burkina Faso v Republic of Mali) (Judgment) [1986] ICJ Rep 554, 556-7 (emphasis altered). 
Moreover, the UN Charter establishes self-determination as a universal principle underlying the state system: not only does the Preamble ascribe authorship of the Charter to 'We the Peoples of the United Nations', but the Charter's articulated moral grounding for the legal principle of sovereign equality in art 2(1) is found in the underlying 'purpose' of developing 'friendly relations among nations based on respect for the principle of equal rights and self-determination of peoples': art 1(2). ${ }^{35}$ Thoroughgoing decolonisation, based on the insistence that '[a]ll peoples have the right to self-determination' and thus a right to 'freely determine their political status', ${ }^{36}$ sought to effectuate for collectivities residing in Non-Self-Governing and Trust Territories a standing presumed to be enjoyed already by the populations of established states, whatever their prevailing governmental systems.

The 1970 Friendly Relations Declaration, after recapitulating the essence of Resolution 1514 and Resolution 1541 of 1960 , added the following 'safeguard clause':

Nothing in the foregoing paragraphs shall be construed as authorizing or encouraging any action which would dismember or impair, totally or in part, the territorial integrity or political unity of sovereign and independent States conducting themselves in compliance with the principle of equal rights and self-determination of peoples as described above and thus possessed of a government representing the whole people belonging to the territory without distinction as to race, creed or colour. ${ }^{37}$

This was a test that Rhodesia and South Africa were intended to fail, but that garden-variety 'scientific socialist' and 'Bandung nationalist' one-party regimes, 'representing' their populations within the terms established by their prevailing ideologies, were intended to pass. ${ }^{38}$

Despite overwhelming international resistance to a right to secession outside the colonial context, self-determination continues to be presented as a right of general applicability. Thus, when India attached to its ratification of the ICCPR a declaration interpreting the right of self-determination in art 1 to 'apply only to the peoples under foreign domination and [not] to sovereign independent States or to a section of a people or a nation', invoking in support of this interpretation 'the essence of national integrity', this declaration drew objections from the Netherlands, France and the Federal Republic of Germany. ${ }^{39}$

35 For the elaboration of the connection between sovereignty and self-determination, viewed from the standpoint of the 'Non-Aligned' bloc that played a central role in Charter interpretation in the post-colonial era, see Djura Ninčić, The Problem of Sovereignty in the Charter and in the Practice of the United Nations (Martinus Nijhoff, 1970).

36 ICCPR art 1; ICESCR art 1.

37 Friendly Relations Declaration, UN Doc A/RES/2625 (XXV) (emphasis added). Subsequent iterations have broadened the last clause of the qualifier to speak of 'a Government representing the whole people ... without distinction of any kind': see Declaration on the Occasion of the Fiftieth Anniversary of the United Nations, GA Res 50/6, UN GAOR, 50 ${ }^{\text {th }}$ sess, $40^{\text {th }}$ plen mtg, Agenda Item 29, UN Doc A/RES/50/6 (9 November 1995); World Conference on Human Rights: Vienna Declaration and Programme of Action, UN Doc A/CONF.157/23 (12 July 1993) [2].

38 See, eg, Antonio Cassese, Self-Determination of Peoples: A Legal Reappraisal (Cambridge University Press, 1995) 115-18, discussing the preparatory work to the safeguard clause, which reveals concessions to non-liberal-democratic states.

39 James Crawford, 'The Right of Self-Determination in International Law: Its Development and Future' in Philip Alston (ed), Peoples' Rights (Oxford University Press, 2001) 7, 28. 
However, the formulation of self-determination as a right possessed by 'all peoples' raises daunting questions. It is not even clear that the statement is anything more than a disguised tautology: since the definition of 'peoples' is not fixed independently of the entitlement to self-determination, it remains open to argue that a grouping is certifiable as a 'people' only once it is ascertained to possess the entitlement. ${ }^{40}$ Article 27 of the ICCPR separately covers 'ethnic, religious or linguistic minorities' within existing states. Whatever academic theories may be brought to bear on the question - including considerations of, for example, religion, race, ethnicity, culture, kinship, territorial separateness or prior conquest - a 'people' is in the final analysis a political community that authoritative organs of the international community acknowledge as such, and such acknowledgment has been hard to come by.

Even 'indigenous peoples', the sub-state groups to which the self-determination right might most plausibly apply, were long explicitly denied this status; tellingly, the 1991 International Labour Organization's Convention Concerning Indigenous and Tribal Peoples in Independent Countries insisted that ' $[t]$ he use of the term 'peoples' in this Convention shall not be construed as having any implications as regards the rights which may attach to the term under international law'. ${ }^{41}$ The 2007 United Nations Declaration on the Rights of Indigenous Peoples, ${ }^{42}$ passed over the dissenting votes of the United States, Canada, Australia and New Zealand, finally ascribed to indigenous peoples the right to self-determination, nominally including the right to 'freely determine their political status', ${ }^{43}$ but pointedly excluding any impairment of existing states' 'territorial integrity or political unity'. ${ }^{4}$ This qualification - which entails a seeming literal contradiction - apparently assuaged African states that had theretofore insisted that the 'principle of self-determination applies only to peoples under colonial and/or foreign occupation'. 45

Instructive as to the ambiguity of 'peoples' is the domestic court decision dealing most elaborately with the international law of self-determination, the Supreme Court of Canada's advisory opinion in Reference re Secession of Quebec. ${ }^{46}$ In deciding that the right, though applicable in the non-colonial context, would not justify the unilateral secession of Quebec, the court managed to sidestep the elemental question of whether the 'people' entitled to self-determination was comprised of (a) the entire Quebec population; (b) the entire Quebec population minus the indigenous communities; (c) Francophone

40 See, eg, Timothy William Waters, 'Contemplating Failure and Creating Alternatives in the Balkans: Bosnia's Peoples, Democracy, and the Shape of Self-Determination' (2004) 29 Yale Journal of International Law 423, 432-5.

41 Opened for signature 27 June 1989, ILO No 169 (entered into force 5 September 1991) art 1(3).

42 GA Res 61/295, UN GAOR, 61 ${ }^{\text {st }}$ sess, $107^{\text {th }}$ plen $\mathrm{mtg}$, Agenda Item 68, UN Doc A/RES/61/295 (2 October 2007, adopted 13 September 2007) ('Declaration on the Rights of Indigenous Peoples').

43 Ibid annex art 3.

44 Ibid annex art 46.

45 African Group, Draft Aide Memoire on United Nations Declaration on the Rights of Indigenous Peoples, (9 November 2006) [3] Indigenous Peoples of Africa Co-ordinating Committee <http://www.ipacc.org.za/uploads/docs/Africanaidememoire.pdf $>$.

46 Reference re Secession of Quebec (Advisory Opinion) [1998] 2 SCR 217. 
Quebecois; or (d) all Francophone Canadians. 47 It stressed merely that none of these groups is blocked from the meaningful exercise of self-determination, since Canada is 'possessed of a government representing the whole people belonging to the territory without distinction'. 48

The most elegant reconciliation of the competing considerations lies in the withholding of recognition to any distinct 'people' wherever an existing state is perceived to extend to all parts of the territorial population (including its 'ethnic, religious or linguistic minorities') some minimally adequate inclusion in the benefits of governance. A 'people' would thus equate to the whole population of an existing state or Non-Self-Governing or Trust Territory - an interpretation consistent with the literal terms of the Friendly Relations Declaration (which refers to 'the whole people belonging to the territory'), though not those of Resolution 1541 (which refers to 'the peoples of the territory') - in the absence of some extraordinary system of oppression. A de jure caste system - especially one, such as apartheid, associated with the international order's 'original sin', Western colonialism - thus overcomes the presumption, vitiating both the state's claim to sovereign inviolability and its claim to encompass one self-determining people. ${ }^{49}$

An arguable implication of the safeguard clause's wording is that, in cases where the arbitrarily subordinated sub-community is territorially coherent (by its nature, rather than by virtue of Bantustans imposed for the oppressors' purposes), such a caste system might prompt the recognition of a separate people

47 Ibid 281-2. For an argument that 'the inhabitants of Quebec' do not constitute a 'people' with a right to self-determination, see Johan D van der Vyver, 'Self-Determination of the Peoples of Quebec under Intemational Law' (2000) 10 Journal of Transnational Law and Policy 1, 21. Interestingly, in 2006, the Canadian House of Commons officially recognised 'that the Québécois form a nation within a united Canada', reportedly intending 'nation' to be understood in a 'cultural-sociological' rather than in a legal sense: 'House Passes Motion Recognising Québécois as Nation', $C B C$ News (online), 27 November 2006 <http://www.cbc.ca/canada/story/2006/11/27/nation-vote.html\#ixzz0rcRZwjMg>. Yet there remains an evident strategic ambiguity about the precise delimitations of this 'nation', an ambiguity similar to that which has plagued the Quebec sovereignty movement. (Upon losing the 1995 sovereignty referendum with 49.4 per cent of the vote, Quebec Premier Jacques Parizeau made bitter remarks about non-Francophone voters that cast doubt on his movement's purportedly inclusionary vision of Quebec nationhood; he was, however, immediately obliged thereupon to resign.) The Parliamentary statement needs to be read alongside two previous unsuccessful constitutional reform proposals that would have recognised Quebec as a 'distinct society'.

48 Reference re Secession of Quebec (Advisory Opinion) [1998] 2 SCR 217, 286-7. But see Crawford, 'The Right of Self-Determination', above n 39, 59-60, construing the Court's position as consistent with 'both the view that self-determination applies to peoples in the ordinary sense of the term, and is not confined to the whole population of existing states, and the view that several peoples may co-exist in relation to a particular territory'; and Patrick Dumberry, 'Lessons Learned from the Quebec Secession Reference before the Supreme Court of Canada' in Marcelo G Kohen (ed), Secession: International Law Perspectives (Cambridge University Press, 2006) 416, 436: the Court's opinion implies 'juxtaposition of many' peoples within Quebec.

49 The idea that the safeguard clause provides a formula for vitiating sovereign inviolability, without a necessary further consequence of establishing peoplehood or licensing territorial fragmentation, may be more promising. Although not accompanied by invocations of such a rationale, the absence of opposition to the 1991 US-UK intervention in Iraqi Kurdistan (not widely discussed as unlawful, despite the absence of express legal authorisation) and of strong, broad-based opposition to the 1999 NATO intervention in Kosovo (widely discussed as unlawful, but as perhaps legitimated by the international order's emerging values) might usefully be seen through this lens. 
with a right to choose its political status (that is, an option on sovereign independence). ${ }^{50}$ Even so, a question would remain as to whether a mere garden-variety de facto, rather than a neo-colonial de jure, system of arbitrary subordination within an existing state, covering the majority of inhabitants of a discrete region, establishes a people entitled 'to choose its political status'. ${ }^{51}$

Although this non-committal interpretation of peoplehood would square the circle, many commentators prefer instead to posit some substantive understanding of the concept, even though none has been authoritatively established. ${ }^{52}$ These commentators do not ascribe to sub-state groups an option on sovereign independence, but instead invoke a 'right to internal self-determination' that reconciles self-determination with inviolability of territorial integrity. ${ }^{53}$ The original authoritative instruments leave little room to read choice of 'political status' as anything short of an option on sovereign independence. But since the 2007 Declaration on the Rights of Indigenous Peoples effectively reduces this language's payoff to 'the right to autonomy or self-government in matters relating to [the indigenous peoples'] internal and local affairs, as well as ways and means for financing their autonomous functions',54 advocates of a group right to internal self-determination for ordinary ethnic, religious or linguistic minorities or historically subordinated regions can take heart.

Outside the special context of indigenous peoples, however, there is no direct international legal mandate for any of the consociational frameworks that certain domestic systems have employed to empower sub-state groups - a wide range of devices that includes territorial autonomy, representational quotas in

50 See, eg, Cassese, above n 38, 120-1. But see Malcolm N Shaw, 'Peoples, Territorialism and Boundaries' (1997) 8 European Journal of International Law 478, rejecting this interpretation of the 'safeguard clause' on the ground, inter alia, that '[s]uch a major change in legal principle cannot be introduced by way of an ambiguous subordinate clause, especially when the principle of territorial integrity has always been accepted and proclaimed as a core principle of international law ...' at 483.

51 The international recognition of Bangladesh, albeit not conferred until Pakistan had conceded the point, might be taken to represent an implicit vindication of this suggestion. Although the UN General Assembly had responded to the 1971 Indian invasion by calling for an immediate withdrawal of forces from foreign territory (Question Considered by the Security Council at Its 1606, 1607 and 1608 Meetings on 4, 5 and 6 December 1971, GA Res 2793, UN GAOR, 2003 ${ }^{\text {rd }}$ plen mtg, UN Doc A/RES/2793 (XXVI) (7 December 1971)) the international community accepted the new state born of India's use of force once Pakistan had been prevailed upon to acquiesce. There were, of course, other factors that might be said to render the case anomalous, such as the former State's territorial noncontiguity and seceding region's encompassing of a majority of the former State's population. For an exploration of the contrasts between this case and failed secessionist efforts, see Islam, above $\mathrm{n} 33$.

52 See, eg, David Raič, Statehood and the Law of Self-Determination (Kluwer Law International, 2002) 226-307; Jane Wright, 'Minority Groups, Autonomy, and Self Determination' (1999) 19 Oxford Journal of Legal Studies 605, 625-7; but see, eg, Gaetano Pentassuglia, Minorities in International Law: An Introductory Study (Council of Europe Publishing, 2002) 168, who insists on an "ethnically and culturally neutral, thus territorially-based notion of a "people"', and similarly Patrick Thomberry, 'Self-Determination, Minorities, Human Rights: A Review of Intemational Instruments' (1989) 38 International and Comparative Law Quarterly 867.

53 See, eg, Raič, above n 52, 226-307; Wright, above n 52, at 628-9; Allan Rosas, 'Internal Self-Determination' in Christian Tomuschat (ed), Modern Law of Self-Determination (Martinus Nijhoff, 1993) 225.

54 Declaration on the Rights of Indigenous Peoples, UN Doc A/RES/61/295 annex art 4. 
governmental and other institutions, super-majority legislative voting rules for group-sensitive subject matter, and much more. 55 Thus far, particular solutions of this nature remain matters of sovereign discretion. While various efforts have been undertaken to confer international status on minority groups as such, ${ }^{56}$ the dominant approach has been to ascribe international rights solely to individual 'persons belonging to such minorities', 57 partly so as to avert an ensuing rivalry between 'national' minorities accorded group rights and 'non-autochthonous' minorities denied them, ${ }^{58}$ and partly so as to avoid endorsing cultural restrictions that an autonomous group might impose on individuals in its midst. ${ }^{59}$

In any event, the putative 'right to internal self-determination' whatever its pedigree or merits, has no specific bearing on the question of secession. The issue remains whether international law provides for a right of secession in case of an extreme de facto violation of the normative expectations that undergird the existing state's right to territorial integrity. In the past, the international order's ideological pluralism, established by accord among discrete First, Second, and Third Worlds, excluded only Axis-era fascism and the vestiges of salt water colonialism. While this pluralism has narrowed substantially in less fraught contexts, the assertion of a more exacting set of normative requisites to the inviolability of territorial integrity, in opening a potential Pandora's Box of secessionist claims, may be incompatible with the international order's overriding imperatives of maintaining peaceful and respectful relations among states as they actually are, and of discouraging the kinds of internal conflicts that tend to exacerbate overall levels of human rights violation.

\section{Non-Consensual Dissolution of Federal States: The Badinter Improvisation}

The doctrinal framework summarised above can be said in some way to encompass (even if it might not compellingly explain) the international responses to almost all secession crises that have occurred in the period of the $U N$ Charter-based order. But at least one substantial outlier remains: the break-up of the SFRY. Investigation of the international opinio juris in reaction to that development is aided by the existence of quasi-authoritative documents establishing a legal rationale: the contemporaneous judgments of the European

55 See, eg, Ruth Lapidoth, Autonomy: Flexible Solutions to Ethnic Conflicts (United States Institute of Peace Press, 1997).

56 See Shaw, above n 50, 486, citing European documents such as the Council of Europe's 1995 Framework Convention for Protection of National Minorities, opened for signature 1 February 1995, CETS No 157 (entered into force 1 February 1998), which 'while extremely cautiously formulated and accompanied by significant provisos', introduced 'a territorial dimension into minority rights within the territorial framework of independent states'.

57 See ICCPR art 27; Declaration on the Rights of Persons Belonging to National or Ethnic, Religious and Linguistic Minorities, GA Res $47 / 135$, UN GAOR, $47^{\text {th }}$ sess, $92^{\text {nd }}$ plen $\mathrm{mtg}$, UN Doc A/RES/47/135 (18 December 1992).

58 See, eg, Sabrina P Ramet, The Three Yugoslavias: State-Building and Legitimation, 1918-2005 (Indiana University Press, 2006) 560, noting this distinction in Slovenian law.

59 See Human Rights Committee, Communication No $R$ 6/24, UN Doc Supp No 40 (A/36/40) (30 July 1981) 166 [19] ('Lovelace v Canada'), in which the Human Rights Committee upholds under ICCPR art 27 the right of an individual member of an indigenous band to the privileges of band membership, from which her previous marriage to a non-indigenous person could not disqualify her. 
Community's Conference on Yugoslavia Arbitration Commission, known by the name of its chair, French Constitutional Council President Robert Badinter ('Badinter Commission'). ${ }^{60}$

The Yugoslav state established after World War I maintained a continuous international legal personality until the early 1990 s, despite major disruptions of its patterns of internal governance, a World War II-era Axis-sponsored de facto secession of an Independent State of Croatia ('NDH') (more or less encompassing the territory of what is now Croatia and Bosnia-Herzegovina), and a series of Socialist-era constitutional reforms that decentralised substantial governmental authority into the hands of regional administrative units bearing distinctive ethnic compositions. The SFRY was constitutionally organised as a federation - made up of six Republics, one of which (Serbia) contained two special autonomous provinces - that recognised its inhabitants as at once Yugoslav citizens, citizens of their respective territorial republics, and members of their respective ethnic groups. ${ }^{61}$ The ruling party's monopoly on power at all levels, operating under the anti-ethno-nationalist banner of 'Brotherhood and Unity', counteracted the tension arising from the imperfect fit between ethnic populations and the territorial boundaries of ethnically-inspired federal units. The unravelling of one-party rule, however, prompted democratisation on a republic-by-republic basis, with ethno-nationalist parties in the lead, while ethno-nationalists from Yugoslavia's largest republic and plurality ethnic group wholly or partially captured institutions at the centre - most importantly, the armed forces. The government of the Republic of Serbia and most of the Serb population of other republics favoured centralisation of Yugoslavia, whereas other elements of the federation - often for economic and political as well as ethnic reasons - sought a transformation that would leave Yugoslavia as, at most, a confederation.

In late 1991, the Badinter Commission confronted the following circumstances: clear majority voter support for independence, expressed in referenda and/or legislative acts, in Slovenia, Croatia, Bosnia-Herzegovina and Macedonia (four of Yugoslavia's six republics); effective establishment of an independent Slovenia after a very brief and decisive armed confrontation with the (Serbian-dominated) Yugoslav People's Army ('JNA'); an ongoing and brutal war in Croatia pitting Croatian Government forces against a combination of JNA forces and Croatian Serb irregulars; manifest militant opposition by the bulk of Bosnia's minority Serb community to the prospect of an independent Bosnian state that would assert authority over Serb inhabitants.

60 Conference on Yugoslavia Arbitration Commission: Opinions on Questions Arising from the Dissolution of Yugoslavia (1992) 31 ILM 1488 ('Badinter Commission Opinions'). For trenchant criticisms of the Badinter Commission's opinions see, eg, Waters, 'Contemplating Failure', above n 40, 438-44; Miodrag Jovanovic, Constitutionalizing Secession in Federalized States: A Procedural Approach (Eleven International Publishing, 2007), 83-114; Peter Radan, 'Yugoslavia's Internal Borders as International Borders: A Question of Appropriateness' (1999) 33 East European Quarterly 137, 137; Peter Radan, The Break-Up of Yugoslavia and International Law (Routledge, 2002).

61 See Susan L Woodward, Balkan Tragedy: Chaos and Dissolution after the Cold War (Brookings Institution, 1995) 29-41. 
Faced with this situation, the Badinter Commission resolved to delegitimate further uses of force across republic boundaries. It did so, however, in a way that is difficult to reconcile with traditional doctrines.

The Commission asserted that:

in the case of a federal-type State, which embraces communities that possess a degree of autonomy and, moreover, participate in the exercise of political power within the framework of institutions common to the Federation, the existence of the State implies that the federal organs represent the components of the Federation and wield effective power ...62

The Commission found, however, that:

The composition and workings of the essential organs of the federation ... no longer meet the criteria of participation and representativeness inherent in a federal state; ...

The recourse to force has led to armed conflict from the different elements of the federation which has caused the death of thousands of people and wrought considerable destruction within a few months. The authorities of the Federation and the Republics have shown themselves to be powerless to enforce respect for ... ceasefire agreements ...63

Since the very existence of the Yugoslav State presupposed functioning federal institutions, the Commission deduced, the collapse of these institutions and the recourse to force entailed nothing less than 'a process of dissolution' of the Yugoslav State into its component republics.

The Yugoslav State was thereby said to be losing its international legal personality, with the six republics collectively succeeding to that personality. ${ }^{64}$ Furthermore, with the disappearance of central authority, the republics' territorial relations inter se were to be governed (even before the territories' objective emergence as states, let alone any formal external recognition) by the venerable principle of uti possidetis, which in the decolonisation context had ascribed to the newly independent states their previous colonial boundaries. ${ }^{65}$

Consequently, the Commission found, the borders of the component republics represented inviolable boundaries as a matter of international law in the course of the 'process of dissolution'. Whatever might be said for a Bosnian Serb right to self-determination, this could not be implemented through forcible changes in the republic boundaries. ${ }^{66}$ Bosnian Serbs might well have wondered why, if Bosnia-Herzegovina could be supported in its secession from Yugoslavia, a Bosnian Serb republic could not equally be supported in its effort to secede from Bosnia; the answer given was that Bosnia had not seceded, but had rather succeeded to a share, demarcated by the republic borders, of the legal personality of the dissolved SFRY.

Whatever merits might be attributed to this set of conclusions, the invocations of traditional doctrines in support of the result must be seen as a sleight of hand. The boundaries of a state's sub-divisions do not ordinarily have international

62 Badinter Commission Opinions (1992) 31 ILM 1488, 1495.

63 Ibid 1496-7.

64 Ibid 1498, 1500.

65 Ibid.

66 Ibid 1497-1500. 
legal significance, nor does international law ordinarily take cognisance of the distinction between a federal and a unitary constitutional structure. ${ }^{67}$ As the Montevideo Convention indicates, '[t]he federal state shall constitute a sole person in the eyes of international law' ${ }^{68}$ There is no traditional reason why a crisis of constitutional authority, even up to and including internal armed conflict, would change this. A corollary of states' 'inalienable right' to choose their political systems is the right (whether carried out by established governments or by successful rebels) to overthrow their constitutions and to reconfigure internal boundaries. A federation's consensual dissolution - indeed, any partition of a state consented to by the effective authorities of all of the succeeding units - would have the effect of creating international legal personality for the new units and international boundaries between them. A non-consensual 'dissolution', however, has a more doctrinally appropriate name: civil war. Such a characterisation would traditionally imply a corresponding duty of foreign states to maintain neutrality pending the outcome, and certainly a duty not to intervene against forces seeking to maintain the state's territorial integrity. ${ }^{69}$

The Badinter Commission's invocation of uti possidetis as a norm of general international law, applicable to the dissolution of central sovereign authority as well as to the withdrawal of colonial authority, is likely correct, ${ }^{70}$ but premature in application. Boundaries become inviolable as a result of a completed dissolution, not at the inception of a 'process of dissolution'. ${ }^{71}$ If there is no mutual consent to dissolution, then dissolution would follow only from a decisive creation (by force, if necessary) of a stable set of new facts on the ground. But of course, such fact creation was precisely what the Commission - for perfectly plausible reasons of morality and policy - sought to pre-empt.

From the perspective of many Serbs, both in the 'rump Yugoslavia' (Serbia and Montenegro) and in Croatia and Bosnia-Herzegovina, this outcome seemed arbitrary. The Commission sought to preclude both an armed struggle to maintain a (Serb-predominant) greater Yugoslavia, on the one hand, and international recognition of Serb-dominated entities seeking secession from the

67 For a statement of the general irrelevance - in either direction - of domestic constitutional law to the international law of secession, see Dumberry, above $n$ 48, at $439-43$.

68 Montevideo Convention art 2.

69 See, eg, Friendly Relations Declaration, UN Doc A/RES/2625 (XXV): 'no State shall ... interfere in civil strife in another State'; 1981 Non-Intervention Declaration, UN Doc A/RES/36/103, annex art 2(f) affirmed ' $[t]$ he duty of a State to refrain from the promotion, encouragement, or support, direct or indirect, of rebellious or secessionist activities within other States, under any pretext whatsoever, or any action which seeks to disrupt the unity or to undermine or subvert the political order of other States' (emphasis added); Convention concerning the Duties and Rights of States in the Event of Civil Strife, opened for signature 20 February 1928, 134 LNTS 45 (entered into force 21 May 1929): Inter-American treaty forbidding "the traffic in arms and war material [sic], except when intended for the Government, while the belligerency of the rebels has not been recognised, in which latter case the rules of neutrality shall be applied': art 1(3); Dietrich Schindler, 'The Principle of Non-Intervention in Civil Wars' (Resolution, Institut de Droit International, 14 August 1975).

70 Some critics have questioned whether this norm applies outside the special context of decolonisation: see Jovanovic, above n 60, 106.

71 Ibid 107. 
newly independent states of Croatia and Bosnia, on the other, thereby thwarting the Serb ethno-national project at both ends. Meanwhile, by predicating Croatian and Bosnian independence on respect for pre-existing internal boundaries amid the crisis of central authority, the Commission effectively vindicated Croat and Bosniak ethno-national projects (which the republic boundaries happened to fulfil) ${ }^{72}$ conveniently without need of recourse to a claim that any of the groups in question constituted 'peoples' with a right of external self-determination.

In the absence of a consensual dissolution, the Commission's analogy to decolonisation breaks down: not only had the colonial borders been external rather than internal, and the newly decolonised entities liberated from the colonial powers rather than from one another, but uti possidetis in that context had represented maintenance of the status quo inter se rather than, as in the Yugoslav context, a drastic shift in power relations among the emergent states' constituent groups. ${ }^{73}$

Of course, the traditional approach outlined above does not provide - nor purport to provide - a principled basis for governing the interaction of these constituent groups; it leaves those as matters 'essentially within the domestic jurisdiction', to be worked out through internal processes, however brutal. In the case of the Yugoslav break-up, the brutality - especially, though not exclusively, on behalf of the Serb ethno-nationalist project - was already becoming manifest.

The Badinter Commission's conclusions find their authentic support not in the application of traditional doctrine, but in a set of emerging values of the contemporary international system. As the Croatian conflict had already demonstrated, an internal war to carve out new territorial units on an ethno-national basis would entail, as an almost inevitable concomitant, the phenomenon of mass expulsions and associated atrocities that has come to be known by the failed euphemism, 'ethnic cleansing'. If an ethno-national project could establish an internationally recognised claim to territory by seizing and holding effective control over it, there would be a natural motivation to purge the territory of populations presumptively loyal to a rival project (and, indeed, even to encourage rivals' expulsions of one's own co-ethnics, who could then be settled in the carved-out territory, completing its demographic transformation). Whereas the international system had once accepted 'population transfer' as a legitimate means of sorting out rival self-determination claims, ${ }^{74}$ that system was now coming to understand both the end and the probable means of such

72 It may be objected that the Republic of Bosnia and Herzegovina was not an ethno-national project, and that some Serbs, especially in cosmopolitan Sarajevo, were loyal to the multi-ethnic Bosnian state. The reality is complex, as different agendas co-existed. By far the leading parties among all ethnic groups were the respective ethno-nationalist parties, and the initial alliance of Bosniak and Bosnian Croat nationalists can be interpreted as tactical (it unravelled into brutal warfare in 1993-94) rather than reflective of any transcendence of ethno-nationalism.

73 Moreover, while the application of uti possidetis discourages violence across the boundary lines, it may actually encourage violence within them: see Radan, 'Yugoslavia's Internal Borders', above n 60, 148, criticising the Badinter framework's role in validating the 1995 Croatian military offensive to reincorporate rebel Serb enclaves, in the course of which 'the great majority of Serbs were expelled from Croatia'.

74 See, eg, Timothy William Waters, 'Remembering Sudetenland: On the Legal Construction of Ethnic Cleansing' (2006) Virginia Journal of International Law 63. 
transfer as 'crimes against humanity'. ${ }^{75}$ The Commission's approach seemed well-calculated to stem a kind of violence, however 'internal', that the international order came to perceive as beyond the pale. ${ }^{76}$

Still, the Badinter Commission approach needs to be understood as a contrivance. The federal boundaries upon which the judgments rely derived their authority exclusively from a domestic constitution. Federally-organised states do not have a different international standing from unitary ones. It is always an error, for purposes of international law, to characterise a constitution as 'constitutive' of statehood; ${ }^{77}$ rather, a constitution presupposes statehood, and

75 See, eg, Rome Statute of the International Criminal Court, opened for signature 17 July 1998, 2187 UNTS 3 (entered into force 1 July 2002) art 7, enumerating crimes against humanity when committed as a 'widespread or systematic attack ... against [a] civilian population'; Prosecutor v Blagojević (Sentencing Judgment) (International Criminal Tribunal for the Former Yugoslavia, Trial Chamber I, Case No IT-02-60-T, 17 January 2005) [595]: 'displacements within a state or across national borders, for reasons not permitted under international law, are crimes punishable under customary international law'.

76 The Badinter Commission's conclusions led, in short order (indeed, in shorter order than their authors had hoped), to the international recognition of (and UN membership for) Slovenia, Croatia, and Bosnia. That speaks well for the efficacy of the work product of international jurists, but alas, it is not the end of the story.

Although the international order conferred recognition on Bosnia and affirmed the legal inviolability of its boundaries, the international community mostly stood by while those same boundaries were grossly violated, and the Bosnian civilian population subjected to sustained and grotesque violence at the hands of forces heavily supplied from across the Serbian border. Indeed, in imposing an arms embargo on the whole of the former Yugoslavia that failed to distinguish aggressor from victim, the Security Council inflicted disparate disadvantage on the defenders of the supposedly sacrosanct Bosnian state, in derogation of that state's 'inherent' right under art 51 of the UN Charter to receive aid from its allies for its self-defence. See, eg, Paul C Szasz, 'Peacekeeping in Operation: A Conflict Study of Bosnia' (1995) Cornell International Law Journal 685, 697.

Insofar as the legal opinions issued at the onset of the Yugoslav conflict by the Badinter Commission, or any international diplomacy set in motion by those opinions, emboldened the Bosnian Government to make a unilateral declaration of independence, over the opposition of a militant Bosnian Serb minority backed by the military power of the army of the dissolving Yugoslavia, it prompted a fatal miscalculation: Szasz at 693: 'to the extent that these opinions encouraged the Bosnian Government to seek early independence, that step provoked [a] disaster'. The international community did not, as it turned out, have the courage of the Commission's convictions.

77 It has been said that '[a] constitution constitutes the People who in tum constitute it': Duncan Ivison, 'Pluralism and the Hobbesian Logic of Negative Constitutionalism' (1999) 47 Political Studies 83, 84, quoted in Zoran Oklopcic, 'Constitutional (Re)Vision: Sovereign Peoples, Constituent Powers and the Formation of Constitutional Orders in the Balkans', in Constellations: An International Journal of Critical and Democratic Theory (forthcoming). It may be that the constitutional document happens to announce - in doctrinal terms, to be 'declaratory' of - the existence of a people that has not heretofore been acknowledged, and that the taking hold of the system of public order embodied in the constitution can be taken as evidence of the existence of a viable political community of the specified contours. But the governmental order that the constitution founds can be recognised as exercising sovereign powers only if it corresponds to an entity that the international community is willing to acknowledge as a bearer of sovereignty; irrespective of the actual chronology, the latter is conceptually prior. 
inherent in statehood is the authority to overthrow the constitution. ${ }^{78}$ Moreover, the creation of a new rule of international law rendering federations more vulnerable to break-up than unitary states would generate perverse incentives, very much at cross-purposes with efforts to effectuate 'internal self-determination' for territorially-concentrated minorities. ${ }^{79}$

While the Badinter Commission judgments might seem consistent with the democratic will of the Yugoslav republics' population, democracy as such can provide no general rule for such circumstances. Abstract democratic principles, even if posited as authoritative, cannot resolve the question of the democratic political community's configuration - what might be referred to, most intuitively, as the 'majority of whom?' problem. The outcome of a plebiscite will depend on who gets to participate; a majority of the residents (perhaps even of the totality of pre-dislocation residents) of the territory of the Bosnian Serb Republic (which has since, ironically, itself become a federal unit) would, if allowed, breach the territorial integrity of Bosnia-Herzegovina, whereas a majority of the whole Bosnian population would disallow this result. It is unhelpful to speak of a democratic decision about the status of a delimited territory when the decision process itself presupposes the territorial delimitation.

\section{E Kosovo and Beyond: The Inevitability of Ad Hoc Responses to Secession Crises}

The final piece of unfinished business from the break-up of the SFRY is the uncertain status of Kosovo. This has given rise to a rare major split in

78 States retain their international legal personality, as well as obligations previously incurred, notwithstanding fundamental changes of governmental order: see, eg, Gabcikovo-Nagymaros Project (Hungary v Slovakia) [1997] ICJ Rep 7, 64, where the Court found that 'profound changes of a political nature' - the collapse of communism - did not amount to a 'fundamental change in circumstances' affecting treaty obligations. The political community is not understood to be re-founded when there is constitutional discontinuity; in Gabcikovo-Nagymaros, it is not that democratic Hungary succeeds to the international legal obligations of communist Hungary, but that the obligations incurred by Hungary's communist government are those of Hungary tout court. Moreover, if '[e]very State has an inalienable right to choose its political, economic, social and cultural systems, without interference in any form by another State': Friendly Relations Declaration, UN Doc A/RES/2625 (XXV): this right against interference necessarily extends to whatever changes in internal political structure may authentically be attributed to 'the State'. James Crawford seems to attribute limitations on Cypriot sovereignty to that State's constitution: see Crawford, Creation of States, above n 7, 89. These, however, are properly traced not to the 1960 constitution, but to the accompanying Treaty of Guarantee that purported to license external armed intervention to enforce adherence to the constitution's terms. The Cypriot government immediately thereafter contended, very plausibly, that this aspect of the treaty violated the United Nations Charter and was therefore legally ineffective: see, eg, Doswald-Beck, above n 2, 246-50; R St J MacDonald, 'International Law and the Conflict in Cyprus' (1981) Canadian Yearbook of International Law 3, 16-17.

79 See Radan, 'Yugoslavia's Internal Borders', above n 60. 
international recognition practice, and an unprecedented reference of the question to the International Court of Justice. 80

The Badinter Commission's theory of Yugoslav dissolution characterised the SFRY as having been constituted by its six republics, not its eight administrative entities (notwithstanding the allocation to Kosovo of a seat on the eight-member SFRY State Council). Thus, Kosovo, a province endowed with autonomous status under the 1974 SFRY Constitution, was understood to be an integral part of the Republic of Serbia, and thus of a new state emerging from SFRY dissolution: the Federal Republic of Yugoslavia - Serbia and Montenegro ('FRY').

The Milošević government's 1989 withdrawal of Kosovo's autonomy and the ensuing pattern of harsh discrimination against the province's large majority of ethnic Albanians precipitated a distinct crisis by the late 1990 s, as an ethnic Albanian insurgency was met by ever more ruthless counterinsurgent efforts. ${ }^{81}$ After the FRY rebuffed Security Council demands that it desist from its norm-offending actions in that territory, ${ }^{82}$ and refused to accede to the comprehensive solution proposed by Western powers in the Rambouillet Accords, 83 the Security Council deadlocked on the question of forcible imposition, setting the stage for the famously unauthorised 79-day NATO air campaign. ${ }^{84}$ Although the Security Council never affirmed the lawfulness of the NATO intervention, it adopted that intervention's fruits in Resolution 1244, precluding the FRY's exercise of territorial control and placing Kosovo under, in effect, an international trusteeship. ${ }^{85}$

While authorising a thoroughgoing transformation of the terms of public order on the ground, Resolution 1244 purported to operate without prejudice to Kosovo's status as an integral part of the FRY. While '[r]eaffirming the

80 Request for an Advisory Opinion of the International Court of Justice on whether the Unilateral Declaration of Independence of Kosovo is in Accordance with International Law, GA Res 63/3, UN GAOR, $63^{\text {td }}$ sess, $22^{\text {nd }}$ plen mtg, Agenda Item 71, UN Doc A/RES/63/3 (8 October 2008) ('Request for an Advisory Opinion on Kosovo'); Accordance with International Law of the Unilateral Declaration of Independence in Respect of Kosovo (Advisory Opinion) (International Court of Justice, General List No 141, 22 July 2010) ('Kosovo Advisory Opinion'); the Court held, 10:4, that the declaration, as such, 'did not violate international law', but declined to address the declaration's legal consequences: [51], [123].

81 See generally Independent International Commission on Kosovo, The Kosovo Report: Conflict, International Response, Lessons Learned (Oxford University Press, 2000) ('Goldstone Commission Report').

82 See SC Res 1160 , UN SCOR, $53^{\text {rd }}$ sess, $3868^{\text {th }} \mathrm{mtg}$, UN Doc S/RES/1 160 (31 March 1998); SC Res 1199, UN SCOR, $53^{\text {rd }}$ sess, $3930^{\text {th }} \mathrm{mtg}$, UN Doc S/RES/1199 (23 September 1998); SC Res 1203, UN SCOR, 53 ${ }^{\text {rd }}$ sess, $3937^{\text {th }} \mathrm{mtg}$, UN Doc S/RES/1203 (24 October 1998) all invoking ch VII powers in addressing the Kosovo situation.

83 Rambouillet Accords: Interim Agreement for Peace and Self-Government in Kosovo, Letter dated 4 June 1999 from the Permanent Representative of France to the UN Addressed to the Secretary-General, UN SCOR, 54 $4^{\text {th }}$ sess, UN Doc S/1999/648 (7 June 2009) annex ('Rambouillet Accords').

84 See Security Council, 'Security Council Rejects Demand for Cessation of Use of Force Against Federal Republic of Yugoslavia' (Media Release, SC/6659, 26 March 1999): Russia, China and Namibia supported a draft Security Council resolution, defeated 3-12-0, which characterised NATO's 'unilateral use of force' as 'a flagrant violation of the United Nations Charter' and demanding 'an immediate cessation' of military operations.

85 SC Res 1244, UN SCOR, $54^{\text {th }}$ sess, $4011^{\text {th }} \mathrm{mtg}$, UN Doc S/RES/1244 (10 June 1999). 
commitment of all Member States to the sovereignty and territorial integrity of the Federal Republic of Yugoslavia', the resolution, inter alia:

10 Authorizes the Secretary-General, with the assistance of relevant international organizations, to establish an international civil presence in Kosovo in order to provide an interim administration for Kosovo under which the people of Kosovo can enjoy substantial autonomy within the Federal Republic of Yugoslavia, and which will provide transitional administration while establishing and overseeing the development of provisional democratic self-governing institutions to ensure conditions for a peaceful and normal life for all inhabitants of Kosovo;

11 Decides that the main responsibilities of the international civil presence will include:

(a) Promoting the establishment, pending a final settlement, of substantial autonomy and self-government in Kosovo, taking full account of annex 2 and of the Rambouillet accords (S/1999/648); 86

(b) Performing basic civilian administrative functions where and as long as required;

(c) Organizing and overseeing the development of provisional institutions for democratic and autonomous self-government pending a political settlement, including the holding of elections;

(d) Transferring, as these institutions are established, its administrative responsibilities while overseeing and supporting the consolidation of Kosovo's local provisional institutions and other peace-building activities;

(e) Facilitating a political process designed to determine Kosovo's future status, taking into account the Rambouillet accords (S/1999/648);

(f) In a final stage, overseeing the transfer of authority from Kosovo's provisional institutions to institutions established under a political settlement 87

86 Ibid. Annex 2 provides, inter alia, for:

5 Establishment of an interim administration for Kosovo as a part of the international civil presence under which the people of Kosovo can enjoy substantial autonomy within the Federal Republic of Yugoslavia, to be decided by the Security Council of the United Nations. The interim administration to provide transitional administration while establishing and overseeing the development of provisional democratic self-goveming institutions to ensure conditions for a peaceful and normal life for all inhabitants in Kosovo....

8 A political process towards the establishment of an interim political framework agreement providing for substantial self-govemment for Kosovo, taking full account of the Rambouillet accords and the principles of sovereignty and territorial integrity of the Federal Republic of Yugoslavia and the other countries of the region ...

87 Ibid [10], [11] (emphasis added). 
The referenced Rambouillet Accords themselves had recalled 'the commitment of the international community to the sovereignty and territorial integrity of the Federal Republic of Yugoslavia' and had sought to confer on Kosovo 'authority to conduct foreign relations within its areas of responsibility equivalent to the power provided to Republics under Article 7 of the Constitution of the Federal Republic of Yugoslavia' ${ }^{88}$ Thus, although nothing in Security Council Resolution 1244 stands in the way of Kosovo independence as an outcome of negotiations, there is nothing in the resolution that makes any affirmative contribution to a legal case for unilateral Kosovo secession from Serbia (which succeeded the FRY in this respect following the 2006 negotiated independence of Montenegro).

Absent either an agreement between Kosovar and Serbian authorities or a new Security Council consensus, the 'interim' Kosovo arrangement is akin to an airplane that has clearance to take off, but never to land. The unsatisfactoriness of this situation, as a matter of both policy and politics, has been widely noted, and given authoritative expression in the Comprehensive Proposal for Kosovo Status Settlement authored in 2007 by the UN Secretary-General's Special Envoy, former Finnish President Martti Ahtisaari.89 Such manifest unsatisfactoriness of the status quo, however, cannot itself constitute legal authority for a departure from existing legal norms.

For a part of the international community, Kosovo independence represents the long-awaited application of the Friendly Relations Declaration's safeguard clause to an existing state that has failed, with respect to an integral territory, to comply 'with the principle of equal rights and self-determination of peoples' by maintaining 'a government representing the whole people belonging to the territory without distinction' 90 Yet that failure is attributable to a past, long-repudiated government of Serbia, whereas the new Serbian political order, which has never had an opportunity to govern the territory, purports a

88 Rambouillet Accords, Preamble ch I art I(6)(c). The document specified that the 'national communities' therein recognised 'shall not use their additional rights to endanger ... the sovereignty and territorial integrity of the Federal Republic of Yugoslavia ...' at Framework art 1(2). The plan also called for 'an international meeting' in three years' time 'to determine a mechanism for a final settlement for Kosovo, on the basis of the will of the people, opinions of relevant authorities, each Party's efforts regarding the implementation of this Agreement, and the Helsinki Final Act ...': ch VIII art 1(3).

89 Martti Ahtisaari, Letter dated 26 March 2007 from the Secretary-General addressed to the President of the Security Council, Addendum: Comprehensive Proposal for the Kosovo Status Settlement, UN Doc S/2007/168/Add.1 (26 March 2007). See generally Jean d'Aspremont, 'Regulating Statehood: The Kosovo Status Settlement' (2007) 20 Leiden Journal of International Law 649.

90 Friendly Relations Declaration, UN Doc A/RES/2625 (XXV). See 'Statement of the Federal Republic of Germany', Accordance with International Law of the Unilateral Declaration of Independency by the Provisional Institutions of Self-Government of Kosovo (Request for Advisory Opinion) [2009] ICJ Pleadings 1, 34-7; see also the Written Statements of Albania, Estonia, Poland and Ireland <http://www.icj-cij.org/docket/ index.php? $1=3 \& \mathrm{p} 2=4 \& \mathrm{k}=21$ \& case $=141$ \& $\operatorname{code}=\operatorname{kos} \& \mathrm{p} 3=1>;$ Kosovo Advisory Opinion (International Court of Justice, General List No 141, 22 July 2010) [173]-[181], [240] (Judge Cançado-Trindade); [11]-[12] (Judge Yusuf). 
willingness to concede the broadest autonomy to the local authorities.91 Moreover, the precedential impact of this application of the safeguard clause has the potential to be highly destabilising, and is strongly resisted by states with territorially-concentrated and restive ethnic minorities. ${ }^{92}$ There is also a potential for perverse incentives, as secessionists may be tempted to commence an armed conflict that they cannot win, thereby provoking a harsh counterinsurgent campaign that can then be cited as evidence that the state, in subjecting the local population to discriminatory predation, has vitiated its claim to territorial inviolability. .3

Meanwhile, insofar as Kosovo authorities have established effective control on the ground, they have been able to do so only by virtue of the shield provided by Resolution 1244, which was not supposed to prejudice Serbia's political unity. Under ordinary circumstances, a secessionist local regime runs the risk that the central government will have recourse to forcible suppression in furtherance of the state's sovereign prerogative to maintain its territorial integrity. Since the Security Council has disabled Serbia's forcible response, thereby relieving the Kosovo authorities of that risk, one cannot argue that Kosovo has established statehood in accordance with the effective control doctrine.

International legal mechanisms have, up to now, simply not provided for a path to secession that is at once peaceful and non-consensual. And yet, it scarcely seems possible nowadays even to invoke, in opposition to Kosovo statehood, the true essence of the traditional doctrinal objection: that the secessionist forces have not prevailed, by their own devices, in a trial by ordeal. Still, while 69 states have recognised Kosovo's statehood as of mid-2010,94 the bulk of the international community can find little appeal in any legal argument for the recognition of Kosovo that does not characterise the matter as somehow sui generis. ${ }^{95}$

The ICJ's 2010 Kosovo Advisory Opinion was obliging in this respect, holding 'the right to separate from a State' to be 'beyond the scope of the question posed by the General Assembly'. ${ }^{96}$ Conveniently, that question had read merely: 'Is the unilateral declaration of independence by the Provisional

91 See, eg, Milan Milosevic, 'Independence or Substantial Autonomy: The Serbian Proposals for Kosovo's Final Status', World Politics Review (online), 10 December 2007 <http://www.worldpoliticsreview.com/articles/1422/ independence-or-substantial-autonomy-the-serbian-proposals-for-kosovos-final-status>.

92 See, eg, the Written Statements of Cyprus, Spain, and the Russian Federation filed with the ICJ in connection with the Kosovo Advisory Opinion proceedings <http://www.icj-cij.org/ docket/index.php?pl=3\&p2=4\&k=21\&case=141\&code=kos\&p3=1>.

93 See, eg, Alan J Kuperman, 'The Moral Hazard of Humanitarian Intervention: Lessons from the Balkans' (2008) 52 International Studies Quarterly 49.

94 Benjamin Bimbaum, 'Serbia Firm Against Recognition of Kosovo', The Washington Times (Washington DC), 1 July 2010.

95 See, eg, 'Statement of the Federal Republic of Germany', Accordance with International Law of the Unilateral Declaration of Independency by the Provisional Institutions of Self-Government of Kosovo (Request for Advisory Opinion) [2009] ICJ Pleadings 1, 26-7.

96 Kosovo Advisory Opinion (International Court of Justice, General List No 141, 22 July 2010) [83]. 
Institutions of Self-Government of Kosovo in accordance with international law?'97 The question, the Court noted,

does not ask about the legal consequences of that declaration. In particular, it does not ask whether or not Kosovo has achieved statehood. Nor does it ask about the validity or legal effects of the recognition of Kosovo by those States which have recognized it as an independent State. ${ }^{98}$

Viewed so narrowly, the question admits of an easy answer: although the rhetoric invoked in particular cases may seem to indicate otherwise, international law is best understood to be indifferent to unilateral declarations of independence as such; it is other states' reactions to the declaration that may or may not accord with international law. 99

As to the merits, the Court limited itself to noting that states have expressed 'radically different views' on: (1) '[w] hether, outside the context of non-self-governing territories and peoples subject to alien subjugation, domination and exploitation, the international law of self-determination [of peoples] confers upon part of the population of an existing State a right to separate from that state'; (2) 'whether international law provides for a right of "remedial secession" and, if so, in what circumstances'; and (3) 'whether the circumstances which some participants maintained would give rise to a right of "remedial secession" were actually present in Kosovo'.100 The effect of the Court's non-decision is to leave Kosovo's trajectory toward statehood

97 Request for an Advisory Opinion on Kosovo, UN Doc A/RES/63/3. Serbia's formulation appears to have been a studied effort to avoid a diplomatic affront to states that had already recognised Kosovo, while at the same time to induce the Court to speak to the declaration's overall implications. That effort appears, in retrospect, to have been too clever, as the majority seized the opportunity to sidestep what everyone understood to be the real issue. In order to seize that opportunity, however, the Court had to make a rather dubious move, asserting - in what amounts to a disguised tautology - that the declarant body, though established as part of the Provisional Institutions of Self-Government of Kosovo under Security Council Resolution 1244, was acting in a different (and yet somehow, not wrongfully ultra vires) capacity: see Kosovo Advisory Opinion (Intemational Court of Justice, General List No 141, 22 July 2010) [102]-[109]. Moreover, the Court's phrasing characterises the declarants as acting 'together in their capacity as representatives of the people of Kosovo outside the framework of the interim administration': at [109], though to infer any legal conclusions about Kosovar 'peoplehood' on this basis would be to overread what Zoran Oklopcic properly calls 'a seemingly off-the-cuff remark': Zoran Oklopcic, 'Preliminary Thoughts on the Kosovo Opinion' on EJIL:Talk! (26 July 2010) $<$ http://www.ejiltalk.org/preliminary-thoughts-on-the-kosovo-opinion>, one that may refer merely to the declarants' subjective understanding of their 'capacity'.

98 Kosovo Advisory Opinion (International Court of Justice, General List No 141, 22 July 2010) [51].

99 In the Court's words, 'the scope of the principle of territorial integrity is confined to the sphere of relations between States': Kosovo Advisory Opinion (International Court of Justice, General List No 141, 22 July 2010) [80]. Where unilateral declarations of independence have been authoritatively condemned as illegal, the Court explained, the illegality 'stemmed not from the unilateral character of these declarations as such, but from the fact that they were, or would have been, connected with the unlawful use of force or other egregious violations of norms of general international law, in particular those of a peremptory character (jus cogens)': at [81].

100 Kosovo Advisory Opinion (International Court of Justice, General List No 141, 22 July 2010) [82]. 
unimpeded, ${ }^{101}$ while simultaneously avoiding any imprimatur that might encourage emulation.

Kosovo may continue to be denied recognition by a significant part of the international community, and thus to be denied membership in intergovernmental organisations, but it is already recognised by most of the states that interact with it systematically. It will thus effectively possess the rights, obligations, powers, and immunities associated with statehood.

Other entities are less favourably situated. By a standard reading of traditional doctrine, Somaliland (as well as, perhaps, neighbouring Puntland) presents a relatively strong case for recognition. ${ }^{102}$ Whereas Kosovo must rely either on a doubtful interpretation of self-determination doctrine or on some sui generis quality, Somaliland appears to have long established effective control through internal processes. 103 As noted above, recognition of seceding entities is, in principle, not precluded where a central government's reunification efforts are manifestly futile for reasons other than foreign interference. Moreover, whereas the Badinter Commission's assertion of Yugoslavia's non-consensual dissolution relied on questionable assertions about a collapse of the governmental order, Somalia has lacked an effective central authority for two decades, and represents a failure of far more than any one constitutional arrangement. And certainly, no argument can be made that respect for democratic values or popular will recommends maintaining this orderly region as an integral part of a state whose name has become synonymous with chaos.

Yet arguments from these objective factors seem unlikely to carry the day at any time in the near future. The fear of total Somali fragmentation - and even more, of the potential demonstration effects - prompts what amounts to a collective decision to ignore all doctrinal principles - lex ferenda as well as lex lata - in favour of simple expediency. The case of Somaliland, like that of Kosovo, bespeaks the ad hoc nature of the international order's solutions to the question of what constitutes a state. ${ }^{104}$

101 The European Union subsequently prevailed upon Serbia to abandon further efforts to harness international mechanisms to impugn Kosovo's status: see 'The UN Urges Direct Talks between Serbia and Kosovo', BBC News (online), 9 September 2010 <www.bbc.co.uk/news>.

102 See, eg, Aaron Kreuter, 'Note: Self-Determination, Sovereignty, and the Failure of States: Somaliland and the Case for Justified Secession' (2010) 19 Minnesota Journal of International Law 363; Alison K Eggers, 'Note: When is a State a State? The Case for Recognition of Somaliland' (2007) 30 Boston College International and Comparative Law Review 211.

103 See, eg, Paul Reynolds, 'Somaliland's "Path to Recognition", BBC News (online), 25 April $2008<w w w . b b c . c o . u k / n e w s>$.

104 Taiwan represents yet another scenario that defies doctrinal solution. I have dealt with this case at length in other writings: see Roth, 'The Entity That Dare Not Speak Its Name', above n 10, 91 and Roth, 'Taiwan's Nation-Building and Beijing's Anti-Secession Law', above $\mathrm{n} 10$. 


\section{EFFECTIVE CONTROL AND THE INTERNATIONAL STATUS OF COUP REGIMES}

\section{A Popular Sovereignty, Ideological Pluralism and the Effective Control Doctrine}

As with recognition of states, there is an ambiguous relationship between what is ordinarily called 'recognition of governments' and an assessment of the legal status of the institution being accorded or denied affirmation. An overt act of recognition is typically a sufficient, but not a necessary, indication of whether a governmental apparatus is thought to bear the legal capacity to assert rights, incur obligations, exercise powers, and confer immunities on behalf of the underlying sovereign entity. Although overt recognition may be withheld as an expression of political disapproval or as an effort to maintain neutrality in internal struggles, some legal obligations owed to the state in question cannot be discerned without ascertaining the government's international legal status.

As Lauterpacht noted:

[t] the problem of recognition of governments arises ... because the accompanying violence and the resulting period of unsettlement demand an answer to the question whether the new government claiming to represent the State is in fact the government of the country. ${ }^{105}$

Efforts to 'abolish' the practice of officially recognising governments, such as the 'Estrada Doctrine' that Mexico famously promulgated in $1930,{ }^{106}$ have typically amounted to a practice of automatic acknowledgment of governments exercising effective control, on the unspoken assumption that effective control has constituted - subject to a few doctrinal qualifications (in particular, rules against premature recognition and foreign-installed regimes) ${ }^{107}-$ the internationally authoritative criterion for an apparatus' standing as the state's government.

The effective control doctrine is best described in draft documents preliminary to the 1950 passage of Resolution $396(\mathrm{~V}), 108$ which took a non-committal position on criteria for the credentialing delegations where 'more than one authority claims to be the government entitled to represent a Member State'. ${ }^{109}$ Although the political support maintained by the Nationalist Chinese government, by then limited in its reach to Taiwan, precluded the establishment of objective criteria, the rejected drafts articulated the position that came to

105 Lauterpacht, above n 6,98.

106 Boletin Oficial de la Secretaria de Relaciones Exteriores, Estados Unidos Mexicanos, (Bulletin, September 1930) [Declaration of Señor Don Genaro Estrada] (1931) 25 American Journal of International Law Supplement (trans) 203: discontinuing the practice of issuing 'grants of recognition, since that nation considers that such a course is an insulting practice and one which, in addition to the fact that it offends the sovereignty of other nations, implies that judgement of some sort may be passed upon the internal affairs of those nations by other governments, inasmuch as the latter assume, in effect, an attitude of criticism when they decide, favourably or unfavourably, as to the legal qualifications of foreign regimes').

107 See Roth, Governmental Illegitimacy, above n 1, 172-99.

108 Recognition by the United Nations of the Representation of a Member State, GA Res 396 (V), UN GAOR, $5^{\text {th }}$ sess, $325^{\text {th }}$ plen mtg, Supp No 20, UN Doc A/1775 (14 December 1950) ('Resolution $396(\mathrm{~V})$ ').

109 Recognition by the United Nations of the Representation of a Member State, GA Res 396, UN GAOR, $5^{\text {th }}$ sess, $325^{\text {th }}$ plen mtg, UN Doc A/RES/396(V) (14 December 1950). 
dominate subsequent UN credentials practice (including, by 1971, practice addressed to the question of Chinese representation). One such document recommended as follows:

where the question of the representation of a Member State arises in consequence of internal processes or changes which have taken place in that State, the right of a government to represent the Member State concerned in the United Nations should be recognized if that government exercises effective control and authority over all or nearly all the national territory, and has the obedience of the bulk of the population of that territory, in such a way that this control, authority and obedience appear to be of a permanent character. ${ }^{110}$

Another contemporaneous document highlighted the relevance of " $[t]$ he extent to which that authority has been established through internal processes in the Member State'.111

The effective control doctrine is rooted in Kelsenian positivism: A new Grundnorm is established when 'the individuals whose behaviour the new order regulates actually behave, by and large, in conformity with the new order'.112

It is often imagined that the advent of popular sovereignty rendered the effective control doctrine obsolete. Yet there is nothing new to the international order about popular sovereignty in the abstract. The time is long past when monarchical regimes were understood to be 'sovereign' over, and not organic parts of, the territorial political communities over which they ruled. ${ }^{113}$ The idea that sovereignty ultimately inheres in the political communities themselves, with governmental apparatuses acting as agents, is at the core of the sovereign equality envisaged in the $U N$ Charter. The question has been and remains how to give it effect.

Popular sovereignty has traditionally been tightly interwoven with a principle of non-intervention in the internal affairs of foreign states and a rejection of any imposition of foreign views as to what constitutes the legitimate government of the state. ${ }^{114}$ Long discredited are international compacts, such as the 1815 Holy Alliance, that pledged to restore to power ousted monarchs bearing 'rightful'

110 Draft Resolution - Resolution 396 (V), $5^{\text {th }}$ sess, Agenda Item 61, UN Doc A/AC.38/L.21/Rev.1 (14 December 1950) annexes, quoted in Roth, Governmental Illegitimacy, above n 1, 258-9.

111 Ibid, 259.

112 Hans Kelsen, General Theory of Law and State (Anders Wedberg trans, Russell \& Russell, 1961) 118. Kelsen elaborated as follows:

Under what circumstances does a national legal order begin or cease to be valid? The answer, given by international law, is that a national legal order begins to be valid as soon as it has become - on the whole - efficacious; and it ceases to be valid as soon as it loses this efficacy. ... The government brought into permanent power by a revolution or coup d'état is, according to international law, the legitimate government of the State, whose identity is not affected by these events. Hence, according to international law, victorious revolutions or successful coups d'état are to be interpreted as procedures by which a national legal order can be changed. Both events are, viewed in the light of international law, law-creating facts. At 220-1.

113 See Maurice Cranston, 'From Legitimism to Legitimacy' in Athanasios Moulakis (ed), Legitimacy/Légitimitié (Walter de Gruyter, 1986) 36.

114 'Every State has an inalienable right to choose its political, economic, social and cultural systems, without interference in any form by another State': Friendly Relations Declaration, UN Doc A/RES/2625 (XXV) Preamble. 
dynastic claims. ${ }^{115}$ As Thomas Jefferson suggested in regard to the French Revolution, recognition of a foreign government has generally turned on the will of the subject people 'substantially declared' - that is, declared by any perceived means of articulation, above all by trends of actual obedience vel non to established authority. ${ }^{116}$ Although the 'Tobar Doctrine', embodied in Central American treaties in 1907 and 1923, sought to deny recognition to seizures of power that violated pre-existing local constitutional norms, this arrangement was as plausibly an effort to thwart as to vindicate popular will, and suffered from the conceptual problem that legal orders themselves have extra-legal origins; the experiment was shortly abandoned.117 The international community's broad-based rejection of Cold War-era ideological legitimism - reflected in such articulations as the 'Brezhnev Doctrine' (rationalising the Soviet invasion of Czechoslovakia) ${ }^{118}$ and the 'Reagan Doctrine' (rationalising the US invasion of Grenada and support of insurgent forces in Nicaragua) ${ }^{119}$ - reaffirmed the principle of deference to whatever internal processes find acceptance, over substantive evaluations of the pedigree or ideological merits of a governing regime. ${ }^{120}$

Popular sovereignty has, of course, also been understood as a standard to which states are bound to adhere in their internal practices. But while internal governmental practices, including modes of political participation, have long been subject to international legal obligations, a governmental apparatus' standing to act in a state's name has not generally been conditioned on compliance with such obligations. ${ }^{121}$ To establish such conditionality would have grave consequences for the doctrine of non-intervention, as a state's government is presumed to have the legal capacity to invite forms of foreign involvement, up to and including a foreign troop presence to maintain or to

115 Lauterpacht, above n 6, 103.

116 Ibid 125-6.

117 See J Izarry y Puente, 'The Doctrines of Recognition and Intervention in Latin America' (1954) 28 Tulane Law Review 313, 317-26; Roth, Governmental Illegitimacy, above n 1, $144-6$.

118 'Pravda Article Justifying Intervention in Czechoslovakia' (1968) 7 ILM 1323 (Novosti Soviet press agency trans): the Soviet Union and its allies 'discharg[ed] their internationalist duty toward the fraternal peoples of Czechoslovakia and defend[ed] their own socialist gains'.

119 See Jeane J Kirkpatrick and Allan Gerson, 'The Reagan Doctrine, Human Rights, and International Law' in Louis Henkin et al (eds), Right v Might: International Law and the Use of Force (Council on Foreign Relations Press, $\left.2^{\text {nd }} \mathrm{ed}, 1991\right) 19$.

120 The ICJ's Nicaragua judgment reached beyond the pleadings to repudiate the Reagan Doctrine-oriented justifications of US efforts to undermine the Nicaraguan government. See Nicaragua [1986] ICJ Rep 14, 130-4. The Court noted that to hold a state's adherence to any particular governmental doctrine a violation of customary international law 'would make nonsense of the fundamental principle of State sovereignty, on which the whole of international law rests, and the freedom of choice of the political, social, economic and cultural system of a State' at 133 [263] (emphasis added).

121 See ibid 130-4: even had there been a violation of a legally binding commitment on the part of Nicaragua to hold elections of a particular type, sovereignty norms would continue to circumscribe the range of lawful responses to such a violation. 
restore order, that would otherwise constitute a violation of arts $2(7)$ and $2(4)$ of the UN Charter. ${ }^{122}$

It is true that art 21(3) of the 1948 Universal Declaration of Human Rights demanded that 'the will of the people shall be the basis of the authority of government'. ${ }^{23}$ This statement (which was not repeated in this provision's legally binding counterpart, art 25 of the ICCPR) could, however, be read in light of ideological pluralism to express nothing more specific than the claim that almost all ruling apparatuses in recent memory have made for themselves. The UN Charter-based order was an accommodation based on the sovereign equality of liberal-democratic and non-liberal-democratic states, and any development of international law required the assent of the Socialist and Non-Aligned as well as Western blocs. Prior to the 1990s, there was neither a political nor legal basis in the international order for calling into question the one-party or military regime that tolerated no organised opposition, but that nonetheless predicated its legitimacy on its supposed embodiment of authentic popular will. ${ }^{124}$

In that context, the effective control doctrine could be seen not as a repudiation of the popular sovereignty norm, but rather as an application of it in those circumstances of ideological pluralism. Contrary to its reputation in some circles as a mere concession to realpolitik or as rank apologism for absolutist

122 See, eg, Doswald-Beck, above n 2; Hafner, above n 2, 242, 253, 255-8. A complicated question arises when insurgent forces achieve such efficacy as to achieve the status of 'belligerent', thereby establishing the existence of a full fledged 'civil war'. Since a government's standing traditionally hinges on its maintenance of effective control through internal processes, the inability of a regime to maintain control by its own devices calls that standing into question, thereby traditionally triggering an obligation of foreign states to observe neutrality: see Convention concerning the Duties and Rights of States in the Event of Civil Strife, opened for signature 20 February 1928, 134 LNTS 45 (entered into force 21 May 1929): Inter-American treaty forbidding "the traffic in arms and war material [sic], except when intended for the Government, while the belligerency of the rebels has not been recognised, in which latter case the rules of neutrality shall be applied': art 1(3); Dietrich Schindler, 'The Principle of Non-Intervention in Civil Wars' (Report, Institut de Droit International, 14 August 1975) <http://www.idi-iil.org/idiE/resolutionsE/ 1975_wies_03_en.pdf>; also cited in Oscar Schachter, 'International Law in Theory and Practice' (1982) 178 Academie de Droit International, Recueil des Cours 160, 160-6. See also Rein Mullerson, 'Intervention by Invitation' in Lori Fisler Damrosch and David J Scheffer (eds), Law and Force in the New International Order (Westview Press, 1991) 127 , 132: ' $[\mathrm{t}]$ he majority of Western authors consider that international law does not forbid the rendering of military assistance at the request of a legitimate government with the aim of restoring order in the case of internal disorders, but that it is nonetheless impermissible to interfere in a civil war, no matter which side makes the request'. Doswald-Beck regards this neutrality rule as having fallen into desuetude: Doswald-Beck, above $n$ 2, 251; but even if it survives formally, the neutrality rule tends to give way because, as a practical matter, successful insurgencies are typically beneficiaries of unlawful foreign assistance, thus triggering a right of counter-intervention in favour of the government's allies: See Roth, Governmental Illegitimacy, above n 1, 185-8.

123 International Bill of Human Rights, GA Res 217, UN GAOR, $3^{\text {rd }}$ Comm, $183^{\text {rd }}$ plen mtg, UN Doc A/RES/217(III)[A-E] (10 December 1948), art 21(3).

124 See generally Roth on 'The Rise and Fall of Revolutionary-Democratic Dictatorship' in Roth, Governmental Illegitimacy, above n 1, 75-120. 
regimes, ${ }^{125}$ the effective control doctrine can be interpreted to embody respect for the self-determination of diverse political communities as to which empirical investigation to ascertain public opinion is most often impracticable. Moreover, given that 'popular will' itself is a complex and normatively-loaded concept, any imposition from abroad of procedures calculated to appropriately measure popular will might be seen as at best presumptuous, and at worst an usurpation. ${ }^{126}$

The case for the effective control doctrine as the most promising application of the principle of popular sovereignty is much more formidable that is commonly supposed. It is hardly clear how to respect popular will in the ordinary case other than by deferring to the apparatus to which the populace has, for

125 See, eg, Fernando Tesón, Humanitarian Intervention: An Inquiry into Law and Morality (Transnational Publishers, 1988) 53: Tesón argues that non-intervention norms are attributable to an organicist 'Hegelian Myth' about the moral standing of the state. See also W Michael Reisman, 'Sovereignty and Human Rights in Contemporary International Law' (1990) 84 American Journal of International Law 866, excoriating the "mystical survival of a monarchical right that supposedly devolves jure gentium on whichever warlord seizes and holds the presidential palace' at 871 .

126 Even General Assembly resolutions on '[e]nhancing the effectiveness of the principle of periodic and genuine elections' have included the pointed caveat that international electoral assistance 'should not call into question each State's sovereign right freely to choose and develop its political, social, economic, and cultural systems, whether or not they conform to the preferences of other States': Enhancing the Effectiveness of the Principle of Periodic and Genuine Elections, UN GAOR, $45^{\text {th }}$ sess, $69^{\text {th }}$ plen mtg, UN Doc A/RES/45/150 (18 December 1990) [4]. Other resolutions have reaffirmed that electoral assistance and support for the promotion of democratization are provided only at the specific request of the Member State concerned': Strengthening the Role of the United Nations in Enhancing the Effectiveness of the Principle of Periodic and Genuine Elections and the Promotion of Democratization, GA Res $49 / 190$, UN GAOR, $49^{\text {th }}$ sess, $94^{\text {th }}$ plen mtg, Agenda Item $100(\mathrm{~b})$, UN Doc A/RES/49/190 (9 March 1995, adopted 23 December 1994). These supportive resolutions have typically been accompanied by counterpart resolutions, passed by majority over the objection of the most strongly liberal-democratic states, that reaffirm 'respect for the principles of national sovereignty and non-interference in the internal affairs of States in their electoral processes', acknowledging the plurality of approaches, reserving to the domestic jurisdiction control over implementation, and criticising unwelcome external influences on local processes: see Respect for the Principles of National Sovereignty and Non-Interference in the Internal Affairs of States in Their Electoral Processes, GA Res 45/151, UN GAOR, $45^{\text {th }}$ sess, $69^{\text {th }}$ plen mtg, UN Doc A/RES/45/151 (18 December 1990); Respect for the Principles of National Sovereignty and Non-Interference in the Internal Affairs of States in their Electoral Processes, GA Res 49/180, UN GAOR, $49^{\text {th }}$ sess, $94^{\mathrm{th}}$ plen mtg, Agenda Item 100(b), UN Doc A/RES/49/190 (2 March 1995, adopted 23 December 1994); Respect for the Principles of National Sovereignty and NonInterference in the Internal Affairs of States in Their Electoral Processes, GA Res 54/168, UN GAOR, 54 ${ }^{\text {th }}$ sess, $83^{\text {rd }}$ plen mtg, Agenda Item 116(b), UN Doc A/RES/54/168 (25 February 2000, adopted 17 December 1999). See also Boutros Boutros-Ghali, An Agenda For Democratization (United Nations Department of Public Information, 1996) 1-3 (the former UN Secretary-General noted that 'individual societies decide if and when to begin democratisation' and that the new emphasis on democratisation 'does not imply a change' in the traditional principle of non-intervention). 
whatever reason, evidently decided to render obedience. ${ }^{127}$ Even where this decision has been made under duress, the populace may not be well served by leaving open the question of who may assert rights, incur obligations, and confer immunities in its name. Having made their peace with the unwanted regime, subjects may plausibly prefer - notwithstanding whatever internal issues remain - that the state's interests in foreign affairs be represented by an apparatus that has both the efficacy and the incentive to do so. They may plausibly wish their ruling apparatus to be able to enter into binding agreements of all kinds on their behalf. They may plausibly demand to be respected in their obedience and service to the only effective instrument of coordination that their political community possesses, and to have any retrospective prosecution of their actions in that service accord with the international standard of nullum crimen sine lege. And they may plausibly regard those powerful foreign states that evince interest (however purportedly 'humanitarian') in their internal affairs not as rescuers, but as potential predators. Albeit paradoxical, it is far from ridiculous that popular sovereignty may amount, as a matter of practical application, to the right to be ruled by domestic thugs rather than by foreigners announcing benevolent intentions.

\section{B Toward a Doctrine of Governmental Illegitimacy in International Law: The Haiti and Sierra Leone Cases}

In the period immediately following the end of the Cold War, however, a substantial literature developed hailing the emergence in international law of a 'right to democratic governance'. ${ }^{28}$ This literature, imputing greater determinacy and consequence to the previously open-textured right to political participation, cast aspersions on the standing of violator governments to assert, in the name of the sovereign state, rights against foreign interference in internal

127 See Mokotso v King Moshoeshoe II [Lesotho High Court, 1988], 90 ILR 427, 519:

[It has been observed] that 'Legality should be achieved only if and when the people accept and approve, for in them lies political sovereignty'. I respectfully observe, however, that the people may well accept without necessarily approving, as such, and the aspect of approval may in any event be difficult if not impossible to determine, except in the clearest of cases. The people make their choice in the matter. If they decide to accept the new regime, even if that decision is based on weakness or even fear, such decision may not be gainsaid. The [judge's] function in the matter ... goes no further than to give effect to the will of the people. Ultimately it is the will of the people, however motivated, which creates a new legal order and the court must recognise this fact and give effect thereto.

128 Separate articles by Thomas Franck and Gregory Fox are now widely cited as the seminal works of this literature: see Thomas $M$ Franck, 'The Emerging Right to Democratic Governance' (1992) 86 American Journal of International Law 46; Gregory H Fox, 'The Right to Political Participation in International Law' (1992) 17 Yale Journal of International Law 539. For an elaboration of contrasting positions on whether and to what extent a 'democratic entitlement' is emerging in intemational law, see Gregory H Fox and Brad R Roth, 'Democracy and Intemational Law' (2001) 27 Review of International Studies 327; see also Gregory H Fox and Brad R Roth (eds), Democratic Governance and International Law (Cambridge University Press, 2000): collection presenting a range of views on related questions; Susan Marks, The Riddle of All Constitutions (Oxford University Press, 2000), assessing the democratic quality of these developments. 
matters. ${ }^{129}$ The implications of such claims for what constitutes a law-governed international response to civil strife are unclear; some (but by no means all) advocates of the 'democratic entitlement' suggest the appropriateness of measures hitherto regarded as inadmissible, up to and including the use of force, to unseat 'non-democratic' regimes. ${ }^{130} \mathrm{~W}$ Michael Reisman's defence of the 1989 US invasion of Panama, which installed an apparently elected government that had been denied accession to power, contained a quintessential statement of this view:

When [the people's] confirmed wishes are ignored by a local caudillo who either takes power himself or assigns it to a subordinate he controls, a jurist rooted in the late twentieth century can hardly say that an invasion by outside forces to remove the caudillo and install the elected government is a violation of national sovereignty. ... [If cross-border military actions] displace the usurper and emplace the people who were freely elected, they can be characterized, in this particular regard, as a violation of sovereignty only if one uses the term anachronistically to mean the violation of some mystical survival of a monarchical right that supposedly devolves jure gentium on whichever warlord seizes and holds the presidential palace or if the term is used in the jurisprudentially bizarre sense to mean that inanimate territory has political rights that pre-empt those of its inhabitants. ${ }^{131}$

Notwithstanding the widespread international condemnation of the Panama invasion, ${ }^{132}$ a sea change occurred shortly thereafter. The international

129 As Fox put it:

[f]or a non-democratic regime to claim that participatory rights violate its national sovereignty begs the question of whether that regime has legitimate authority to make such a statement. When the will of the people is the basis of the authority of government, regimes that thwart the will of the people lack legitimacy. ... [I]f political participation is to have any meaning as an internationally enforceable right, the community of states must be empowered to prescribe standards detailing how participation is to occur and to insist that parties to the major treaties adopt these standards as law. A regime that bases its legitimacy on nothing more than the fact that it holds power exercises no 'sovereign' authority to object to such prescriptions.

Fox, above $\mathrm{n} 128,595$ (emphasis in original).

130 For elaboration, see Fox and Roth, above n 128, 335-8.

131 Reisman, 'Sovereignty and Human Rights' above n 125, 871. For similar views, see Lois Fielding, 'Taking the Next Step in the Development of New Human Rights: The Emerging Right of Humanitarian Assistance to Restore Democracy' (1995) 5 Duke Journal of Comparative and International Law 329; Malvina Halberstam, 'The Copenhagen Document: Intervention in Support of Democracy' (1993) 34 Harvard Journal of International Law 143; Anthony D'Amato, 'The Invasion of Panama Was a Lawful Response to Tyranny' (1990) 84 American Journal of International Law 516; but see Thomas M Franck, The Empowered Self: Law and Society in the Age of Individualism (Oxford University Press, 1999) 272-3, asserting Security Council authority to license 'military rescue of democracy', but insisting 'that [i]nternational law does not ... permit any state, or any regional organization, to take enforcement of the democratic entitlement exclusively into its own hands'. For a detailed study of the international law of collective non-recognition of governments, with a critical assessment of the claims for the emergence of a democratic entitlement as of 1999, see Roth, Governmental Illegitimacy, above $\mathrm{n} 1$.

132 By a vote of 75 to 20 , with 40 abstentions, the UN General Assembly characterised the intervention as 'a flagrant violation of international law and of the independence, sovereignty and territorial integrity of States': Effects of the Military Intervention by the United States of America in Panama on the Situation in Central America, GA Res 44/240, UN GAOR, $44^{\text {th }}$ sess, $88^{\text {th }}$ plen mtg, UN Doc A/RES/44/240 (29 December 1989) [1]. 
community authoritatively repudiated the 1991 overthrow of Haitian President Jean-Bertrand Aristide and the 1997 ouster of Sierra Leonean President Ahmad Tejan Kabbah, even though the changes in government were effectively achieved through internal processes. These international responses went far beyond a denial of 'recognition', in the diplomatic or political sense of that term. Rather, the authority of the de facto regime was deemed to be null and void for purposes of international law, including for purposes of asserting the state's theretofore supposedly 'inalienable' right against forcible intervention. ${ }^{133}$ In the Haitian case, following a request from the government-in-exile for 'swift and determined action,' the Security Council ultimately authorised force 'to assist the legitimate Government of Haiti in the maintenance of public order', ${ }^{134}$ whereas in the Sierra Leone case, the Council implicitly encouraged the armed forces of the Economic Community of West African States ('ECOWAS') to effectuate the Kabbah government's restoration, and subsequently 'welcome[d] the fact that the military junta ha[d] been brought to an end'. ${ }^{135}$

There was, nonetheless, much reason to resist an overreading of these events: while much had changed, even more had thus far remained the same. The international repudiations, dramatic though they were, seemed to represent incremental rather than radical change. While these coups had been directed against both established constitutional orders and unambiguous electoral outcomes, the strength of the international response did not clearly rest on an attribution of decisive significance to either of these factors. The facts on the ground in each case were exceptional - including the landslide victory of the ousted President in a very recent, intemationally-monitored election, and the notorious brutality and demonstrable unpopularity of the forces involved in the coup - leading a vast diversity of international actors, cutting across the international system's plurality of interests and values, to perceive in common a population's manifest will to restore an ousted government. ${ }^{136}$ Although other coups might be disfavoured politically, or even regarded as breaches of binding international commitments, there was no immediate indication of a general rule that an internal seizure of effective control would be ineffective in establishing a regime's standing to exercise the state's sovereign rights in the international

133 In these cases, the Security Council deemed coups against the elected governments to be threats to international peace and security: see SC Res 841 , UN SCOR $48^{\text {th }}$ sess, $3238^{\text {th }} \mathrm{mtg}$, UN Doc S/RES/841 (16 June 1993) (unanimous vote on economic sanctions against Haiti); SC Res 1132, UN SCOR, 52 ${ }^{\text {nd }}$ sess, $3822^{\text {nd }} \mathrm{mtg}$, UN Doc S/RES/1132 (8 October 1997) (unanimous vote on arms and oil embargo against Sierra Leone). Ultimately, the Security Council authorised armed intervention in Haiti through SC Res 940, UN SCOR, $49^{\text {th }}$ sess, $3413^{\text {th }} \mathrm{mtg}$, UN Doc S/RES/940 (31 July 1994), and gave the forcible restoration of the Sierra Leonean President a post hoc imprimatur, welcoming the removal of the Sierra Leonean junta: Statement by the President of the Security Council, $53^{\text {rd }}$ sess, $3857^{\text {th }} \mathrm{mtg}$, UN Doc S/PRST/1998/5 (26 February 1998); and commending ECOWAS after the fact for its role in the Sierra Leonean transition, SC Res 1162 , UN SCOR, $53^{\text {rd }}$ sess, $3872^{\text {nd }} \mathrm{mtg}$, UN Doc S/RES/1162 (17 April 1998) [2]. For elaboration, see Roth, Governmental Illegitimacy, above $n$ 1, 366-87, 405-10.

134 SC Res 940 , UN SCOR, $49^{\text {th }}$ sess, $3413^{\text {th }} \mathrm{mtg}$, UN Doc S/RES/940 (31 July 1994).

135 Statement by the President of the Security Council, $53^{\text {rd }}$ sess, $3857^{\text {th }} \mathrm{mtg}$, UN Doc S/PRST/1998/5 (26 February 1998).

136 For elaboration, see Roth, Governmental lllegitimacy, above n 1, 366-87, 405-10. 
order. ${ }^{137}$ The tepidness of reactions against subsequent coups - including, ironically, the 2004 ouster of Haiti's Aristide - bolstered the conclusion that the 1991-94 Haitian crisis and the 1997-98 Sierra Leonean crisis were outlier cases.

\section{The Anti-Coup Proclamations of Regional Organisations}

Nonetheless, both in Latin America and in Africa, regional organisations have begun to take progressively more adverse positions toward disruptions of existing constitutional orders. Given how strongly the non-interventionist hard line was previously associated with both the Organization of American States ('OAS') and the Organization of African Unity, predecessor to the African Union ('AU'), these developments are striking.

The OAS Charter affirms that ' $[\mathrm{t}]$ he solidarity of the American States and the high aims which are sought through it require the political organization of those States on the basis of the effective exercise of representative democracy'.138 The OAS Charter nonetheless simultaneously provides that ' $[\mathrm{n}] \mathrm{o}$ State or group of States has the right to intervene, directly or indirectly, for any reason whatever, in the internal or external affairs of any other State', elaborating further that the prohibition extends beyond the use of force to 'any form of interference', with special reference to 'coercive measures of an economic or political character'. 139 Although the OAS Charter anticipates '[m]easures adopted for the maintenance of peace and security in accordance with existing treaties', the non-intervention norm otherwise prevails in the face of 'any reason whatever', and applies 'not only [to] armed force but also [to] any other form of interference or attempted threat against the personality of the State or against its political, economic, and cultural elements'. ${ }^{140}$

137 Seemingly to the contrary, Jean d'Aspremont asserts that 'the recognition of overthrown democratic governments is generally not questioned and the recognition of putschists [is] systematically denied': Jean d'Aspremont, 'Responsibility for Coups d'État in International Law' (2010) 18 Tulane Journal of International and Comparative Law 451, 455-6.

But d'Aspremont immediately makes clear that once 'the authors of a coup d'état ... have gained effective power', they become for legal purposes 'an organ of the state', and their subsequent breaches of international legal obligation 'are attributable to the state': at 473 . Thus, whatever may be said about 'the systematic condemnations and sanctions against coups carried out against democratically-elected governments': Jean d'Aspremont, 'Legitimacy of Governments in the Age of Democracy' (2006) $38 \mathrm{New}$ York University Journal of International Law and Politics 877, 893; but see Mikulas Fabry, 'The Right to Democracy in International Law: A Classical Liberal Reassessment' (2009) 37 Millennium Journal of International Studies 721, 735: responses to coups 'have varied not just across different organisations or countries, but also in the course of the same organisations' or countries' treatment of nominally like cases', these political reactions do not ordinarily rise to the level of a denial of a coup regime's legal standing to represent the state for purposes of international law. D'Aspremont does not invoke any examples of international reactions matching those that followed the 1991 Haitian and 1997 Sierra Leonean coups.

138 Charter of the Organization of American States, 119 UNTS 3 (1952) art 3(d) ('OAS Charter').

139 Ibid arts 19,20 . These points are reiterated elsewhere in the OAS Charter to the point of redundancy. Under art 3(b), '[i]nternational order consists essentially of respect for the personality, sovereignty, and independence of States, and the faithful fulfilment of obligations derived from treaties and other sources of international law'. Article 3(e) also provides that '[e]very State has the right to choose, without external interference, its political, economic, and social system and to organize itself in the way best suited to it, and has the duty to abstain from intervening in the affairs of another State'.

140 Ibid arts 19, 23. 
In the decades leading up to the $1990 \mathrm{~s}$, both an increased diversity of governmental forms and ideologies in Latin America and an increase in nationalistic self-assertion as a counter to United States hegemony ensured that the non-intervention norm would predominate in OAS practice. ${ }^{141}$ Indeed, this period's singular OAS repudiation of an existing government, the pathbreaking 23 June 1979 resolution calling for the 'immediate and definitive replacement of the Somoza regime' in Nicaragua, ${ }^{142}$ came in the context of a rebuff to a US effort to interject 'peacekeeping' forces against the will of an insurrectional movement that was less than a month from outright victory. ${ }^{143}$

However, in June 1991, the OAS General Assembly convened in Santiago, Chile and promulgated two documents espousing representative democracy as 'the form of government of the region' ${ }^{144}$ The first, the Santiago Commitment to Democracy and the Renewal of the Inter-American System, assigned 'special priority' to, inter alia, '[s]trengthening representative democracy as an expression of the legitimate and free manifestation of the will of the people', albeit 'always respecting the sovereignty and independence of member states'. 145 The second, entitled Representative Democracy, more concretely mandated:

in the event of any occurrences giving rise to the sudden or irregular interruption of the democratic political institutional process or of the legitimate exercise of power by the democratically elected government in any of the Organization's member states ... [an immediate] ad hoc meeting of Ministers of Foreign Affairs [or] the special session of the General Assembly [to take decisions] deemed appropriate, in accordance with the Charter and international law. ${ }^{146}$

No doubt, the Santiago documents indicated a new emphasis in the inter-American system on participatory mechanisms in the hemispheric scheme of popular sovereignty. Yet the dual emphasis on representative democracy and non-intervention norms that marks the OAS Charter and previous OAS pronouncements was merely recapitulated in these documents. The Representative Democracy resolution's preambular promise to promote democracy was qualified by the words 'with due respect for the principle of

141 The OAS General Assembly declared in 1973 that 'every state has the right to adopt, with complete independence, its own system of government and economic and social organization': Reference Principles for Relations between the American States, OAS GA Res 128(III-O/73), OAS GAOR, $3^{\text {rd }}$ sess, OAS Doc AG/RES 128 (III-O/73) (15 April 1973).

142 The 1979 resolution did not, however, unseat the Somoza Government's representative to the OAS, nor did it overtly call for member states to take measures calculated to bring down that Government: OAS GA Res XXX, $9^{\text {th }}$ sess, $17^{\text {th }}$ plen mtg, OAS Doc OEA/Ser.F/IL.17 Doc $43 / 79$ (23 June 1979) art 1.

143 See Roth, Governmental lllegitimacy, above n 1, 290-303.

144 Santiago Commitment to Democracy and the Renewal of the Inter-American System, OAS GAOR, $21^{\text {st }}$ sess, $3^{\text {rd }}$ plen mtg, OAS Doc OEA/SerP/AG Doc 2734/91 (4 June 1991) Preamble [4].

145 Ibid [3(b)].

146 Representative Democracy, OAS GA Res 1080 (XXI-O/91), OAS GAOR $21^{\text {st }}$ sess, $5^{\text {th }}$ plen sess, OAS Doc OEA/SerP/XXIO2 Doc 2739/91 (5 June 1991). 
non-intervention'. ${ }^{147}$ How much respect is 'due' was, of course, the open question, but the operative provision of the resolution - authorising a meeting 'to look into the events collectively and adopt any decisions deemed appropriate' 148 - merely begged this question by referring to the OAS Charter and international law. Not only is collective de-recognition not directly proposed, but the preamble also emphasises that '[d]ue respect must be accorded to the policies of each member country in regard to the recognition of states and governments'. ${ }^{149}$

The Santiago documents were followed by further pro-democratic OAS proclamations, including a 1992 Protocol of Washington amendment to the OAS Charter allowing recourse to suspension, by two-thirds vote of the General Assembly, of a member state 'whose democratically constituted government has been overthrown by force'. 150 Most dramatically, in a 2001 General Assembly resolution styled as the Inter-American Democratic Charter ('IADC'), 151 the Organization proclaimed that:

an unconstitutional interruption of the democratic order or an unconstitutional alteration of the constitutional regime that seriously impairs the democratic order in a member state, constitutes, while it persists, an insurmountable obstacle to its government's participation in sessions of [OAS organs]. ${ }^{152}$

Beyond suspension of the state - a measure which, by its nature, seems to presuppose that the offending regime has the status of the state's government - the $I A D C$ calls, rather vaguely (having twice referenced the OAS commitment to 'due respect for the principle of nonintervention'), for such decisions as the Permanent Council and the General Assembly deem

147 Ibid Preamble [2].

148 Ibid.

149 Ibid Preamble [3]. In December 1992, the OAS General Assembly proposed a Charter amendment (the 'Protocol of Washington'), which entered into force in 1997, providing that a member state whose 'democratically elected govemment has been overthrown by force may be suspended from the exercise of its right to participate in the meetings of the General Assembly' and of other OAS bodies: Protocol of Washington, opened for signature 14 December 1992, 33 ILM 1005 (entered into force 25 September 1997). Importantly however, the amendment does not provide for continued recognition of the ousted 'democratically elected government', or cast any other aspersions on the de facto government's standing as the state's diplomatic and legal representative.

150 OAS Charter, 11 UNTS 3 (1948) art 9.

151 Inter-American Democratic Charter, opened for signature 11 September 2001, 40 ILM 1289 (entered into force 11 September 2001). Although not a 'charter' in the sense of a binding treaty, the $I A D C$ can be regarded under art 31(3)(a) of the Vienna Convention on the Law of Treaties as an authoritative interpretation of the OAS Charter: see Vienna Convention on the Law of Treaties, opened for signature 23 May 1969, 1155 UNTS 331 (entered into force 27 January 1980) ant 31(3)(a); see also Doug Cassel, 'Honduras: Coup d'Etat in Constitutional Clothing?' (2009) American Society of International Law Insight, <http://www.asil.org/ files/insight090729pdf.pdf>.

152 Declaration of Lima: Inter-American Democratic Charter, OAS GA Res 1 (XXVIII-E/01), $28^{\text {th }}$ sess, OAS Doc OEA/SerP/AG/Res 1 (XXVIII-E/01) (11 September 2001) Preamble art 19 (emphasis added). 
'appropriate, including the undertaking of diplomatic initiatives, in accordance with the Charter of the Organization, international law, and the provisions of this Democratic Charter'.153

Apart from its strong stance in the exceptional 1991-94 Haitian crisis, the Organization's overall record of responses to interruptions of constitutional governance - such as have occurred in Peru, Guatemala, Paraguay, Ecuador, and Venezuela - has been less than dramatic. ${ }^{154}$ The OAS pronouncements nonetheless potentially portend a significant departure from past positions on the attribution of international legal standing to governments, a departure emphasising both electoral outcomes and adherence to established constitutional process over effective control through internal processes. The 2009 Honduran crisis, discussed below, provides an indication of how substantial a shift might be in the offing.

Similarly, the 2000 Constitutive Act of the African Union, best known for asserting "the right of the Union to intervene in a Member State pursuant to a decision of the Assembly in respect of grave circumstances, namely: war crimes, genocide and crimes against humanity', also espouses the principle of 'condemnation and rejection of unconstitutional changes of governments'. 155 In 2007, the AU adopted the African Charter on Democracy, Elections, and Governance (' $A C D E G$ '), though very few of its members have thus far ratified the document (which requires fifteen ratifications to take effect). ${ }^{156}$ Article 25 of the $A C D E G$ starts with a familiar call for suspension upon a finding of 'an unconstitutional change of government', 157 but unlike the OAS documents, goes

153 Ibid Preamble art 20.

154 See, eg, Barry S Levitt, 'A Desultory Defense of Democracy: OAS Resolution 1080 and the Inter-American Charter' (2006) 48 Latin American Politics and Society 93; Dexter S Boniface, 'Is There a Democratic Norm in the Americas? An Analysis of the Organization of American States,' (2002) 8 Global Governance 365.

155 AU, Constitutive Act of the African Union (11 July 2000) art 4(p).

$156 \mathrm{AU}$, African Charter on Democracy, Elections and Governance (30 January 2007) ('ACDEG'); see also Tajudeen Abdul-Raheem, 'Why No-One Will Ratify The AU Charter on Democracy' Africa Files (9 May 2009) <http:// www.africafiles.org/article.asp?id=20794>.

$157 A C D E G$ art 23 defines 'an unconstitutional change of govemment' as:

1 Any putsch or coup d'etat against a democratically elected government.

2 Any intervention by mercenaries to replace a democratically elected govemment.

3 Any replacement of a democratically elected government by armed dissidents or rebels.

4 Any refusal by an incumbent government to relinquish power to the winning party or candidate after free, fair and regular elections; or

5 Any amendment or revision of the constitution or legal instruments, which is an infringement on the principles of democratic change of government. 
on to specify a menu of responses that altogether leaves behind the principle of non-intervention:

4 The perpetrators of unconstitutional change of government shall not be allowed to participate in elections held to restore the democratic order or hold any position of responsibility in political institutions of their State.

5 Perpetrators of unconstitutional change of government may also be tried before the competent court of the Union.

6 The Assembly shall impose sanctions on any Member State that is proved to have instigated or supported unconstitutional change of government in another state in conformity with Article 23 of the Constitutive Act.

7 The Assembly may decide to apply other forms of sanctions on perpetrators of unconstitutional change of government including punitive economic measures.

8 State Parties shall not harbour or give sanctuary to perpetrators of unconstitutional changes of government.

9 State Parties shall bring to justice the perpetrators of unconstitutional changes of government or take necessary steps to effect their extradition.

10 State Parties shall encourage conclusion of bilateral extradition agreements as well as the adoption of legal instruments on extradition and mutual legal assistance. ${ }^{158}$

The very boldness of these remedies, contrasted with the realities of undemocratic and unconstitutional governance in so many of the states that voted to approve it, calls into question how seriously this instrument can be taken. At worst, the document might serve as a compact among a clique of unaccountable leaders to suppress challenges to one another's control. Still, the $A C D E G$ represents an unprecedented withholding of respect for the outcome of internal processes judged to transgress international standards.

\section{The New Wave of Rejection of Coup Regimes: Honduras and Madagascar}

Where blatantly thuggish forces impose themselves on a manifestly unwilling political community, deference to the outcomes of 'internal processes' cannot be rationalised as respect for the self-determination of independent political communities. Ideological pluralism, however foundational to the international legal order, ultimately finds its limiting cases, where no internationally respected principles of public order support the governmental pretensions of narrowly self-interested cliques and glorified street gangs. The exceptional cases of Haiti and Sierra Leone might thus be seen as helping to stabilise, rather than to undermine, the general presumption in favour of the effective control criterion. Coup regimes might be subjected to diplomatic disapproval, and sanctioned for breaches of human rights obligations, including a more robustly read right to

$158 A C D E G$ art 25. 
political participation, yet might still be accepted as embodying valid domestic authority for purposes of analysing the state's rights and obligations under international law.

But new cases may point in a different direction. Most dramatic has been the international reaction to the 28 June 2009 ouster of Honduran President Manuel Zelaya. When the Honduran military, with the overwhelming support of the legislature and the unanimous support of the Supreme Court, summarily removed and exiled Zelaya in apparent defiance of the Constitutional text, the international reaction to the equivocal circumstances was remarkably unequivocal: the UN General Assembly unanimously demanded Zelaya's immediate restoration and called 'firmly and unequivocally upon States to recognize no Government other than that of the Constitutional President'. ${ }^{159}$ Accordingly, UN bodies refused to accept the credentials of the coup regime's representatives. 160

The Honduran case is difficult to contain within a traditional framework. Far from holding an overwhelming popular mandate, Zelaya was a narrowly elected President nearing the end of his term, disowned by his own political party, and increasingly given to polarising and apparently unconstitutional measures (whether for worse or, just as plausibly, for better); Honduras was a divided society. ${ }^{161}$

The case for the continued recognition of Zelaya rested exclusively on an interpretation of the Honduran Constitution that, however well grounded in the text, was overwhelmingly rejected by established Honduran judicial and legislative institutions. While it is not implausible to regard the Honduran Supreme Court as both a partisan political player and a malefactor, ${ }^{162}$ it seems incongruous for outsiders to second-guess even a highly counterintuitive constitutional interpretation issued by a foreign high court - a unanimous one, no less. As Doug Cassel notes:

Ordinarily international law imposes its own, autonomous norms for the permissible conduct of a government. Questions of domestic law - including constitutionality - are left to domestic authorities, both as a matter of their sovereign entitlements, and because they are presumed better able to interpret their own constitution. ${ }^{163}$

The two reasons that Cassel cites are distinct. The latter is a matter of respect for a foreign pouvoir constitué, on the ground that standards of legal interpretation are themselves a matter of local law. The former is a matter of

159 Situation in Honduras: Democracy Breakdown, GA Res 63/301, UN GAOR, 63 ${ }^{\text {rd }}$ sess, $93^{\text {rd }}$ plen mtg, Agenda Item 20, UN Doc A/RES/63/301 (1 July 2009) ('Resolution 63/301').

160 Gustavo Capdevila, 'Tripped Up by Honduras, UN Council Tums to Middle East', Inter Press Service News Agency (online), 15 September 2009 <http://ipsnews.net

161 A CID-Gallup poll showed 46 per cent opposed to the coup versus 41 per cent in favour: 'Honduras: "A Divided Nation"” (Public Opinion Poll, CID-Gallup, July 2009) $<$ http://www.cidgallup.com/ Documentos/Boletin_OP_HONDURAS_71\%20Englishv2.pdf>.

162 Larry Birns, director of the Washington-based Council on Hemispheric Affairs, has characterised the Honduran Supreme Court as 'one of the most corrupt institutions in Latin America': Larry Birns, quoted in 'Police Clash with Demonstrators in Honduran Capital', CNN.com (online), 29 June $2009<$ ttp://edition.cnn.com/2009/WORLD/americas/06/29/ honduras.president.arrested/index.html?iref=storysearch $>$.

163 Cassel, above n 151 . 
respect for a foreign pouvoir constituant, on the ground that where permanently effective, breaches of constitutional order (whether by insurrection or by an existing regime's pattern of practice) beget their own legality. ${ }^{164}$ For foreign courts, both of these are ordinarily rationales, not for a mere 'margin of appreciation', but for judicial abstention.

However, it is not unknown for international legal questions to turn on a finding about compliance with domestic law, such as where treaty provisions provide that exceptions to specified human rights must be, inter alia, 'non-arbitrary' and delineated in domestic law. In such circumstances, assessing a claim of violation requires an independent basis for ascertaining the requirements of domestic law. The criteria for establishing a violation might be relatively deferential, yielding to plausible claims of local expertise in interpreting local norms; interpretation of legal (including especially constitutional) norms depends on all manner of historical, ideological, political, linguistic, and jurisprudential idiosyncrasies, and a high court's authority to say what is lawful counts for much, even in the face of text apparently to the contrary. Still, one cannot exclude a second-guessing of local judicial authorities on the merits, especially in cases where courts are suspected of participating in a sham.

As Cassel points out, 'In order to create a collective regional safeguard for democracy in each country, [the $I A D C$ ] sets international standards which demand (among other things) that each nation comply with its own constitution'. ${ }^{165}$ This much is established: a state's compliance with the IADC, and thus, at minimum, with OAS terms for participation, turns on a determination about compliance with domestic law. Compliance with the IADC and domestic law may also bear on the state's fulfilment of the requirements of the right to political participation under art 23 of the American Convention on Human Rights. ${ }^{166}$

But here, at issue is which of two putative Presidencies validly represents Honduras in the international order. From the standpoint of international law, such a controversy would ordinarily be thought to represent quintessentially a 'matter essentially within the domestic jurisdiction' under art 2(7) of the $U N$ Charter and related norms of non-intervention in internal affairs. Indeed, it is hardly an exaggeration to say that if internal actors do not retain the last word on such a matter, the whole idea of a 'matter essentially within the domestic jurisdiction' is now a nullity (and, some would say, a good riddance).

Herein lies a subtle, but crucial distinction: states may undertake international legal obligations in respect of any subject matter whatever, but doing so does not, in itself, render breaching acts legally null and void. To be sure, contrary domestic law is not a defence to a breach of an international legal obligation, but it does not automatically follow that the international order can ignore all legal facts that the breaching act purports to establish, especially as they pertain to public order within the state's territory. For example, foreign states generally

\footnotetext{
164 'Successful revolution sooner or later begets its own legality': Stanley A de Smith, Constitutional and Administrative Law (Penguin, $3^{\text {rd }}$ ed, 1977) 66-7.

165 Cassel, above $\mathbf{n} 151$.

166 American Convention on Human Rights, opened for signature 22 November 1969, 1144 UNTS 123 (entered into force 18 July 1978).
} 
lack jurisdiction to enforce even a binding and applicable international legal norm within the territory of a fellow sovereign state, even where the latter's cooperation is unlawfully withheld, and state officials acting within national territory are ordinarily immune ratione materiae for their participation in acts of state that breach international obligations. International law contains no analogue to the US Constitution's Supremacy Clause; ${ }^{167}$ the relationship of Honduras to the international or the regional order cannot be analogised to that of Michigan to the US federal government.

It is unclear how far the international system's reaction to the Honduran case entailed a literal assertion that the Zelaya Government, and not the Congressionally installed Micheletti Government, represented the Honduran state for purposes of international law. For example, it is one thing for the OAS to suspend 'Honduras'; it is quite another thing for states and international organisations to acknowledge a government-in-exile as exercising the authentic executive aspect of Honduran sovereignty. Interestingly, when the de facto regime sought to pre-empt suspension by withdrawing Honduras from the Organization, OAS Assistant Secretary-General Albert R Ramdin responded that ' $[\mathrm{t}$ ]he current regime is not recognized as the legitimate government of Honduras. And so only a legitimate government can withdraw from the organization'. ${ }^{168}$ How seriously this statement was intended, and how far its implications were deliberated, remain open questions. The OAS Charter, even read in light of the $I A D C$ and related declarations, contains no language that would seem to authorise the coercive consequences that might follow from a finding that the government-in-exile bears the Honduran state's power of sovereign consent.

Two factors may render this case somewhat less profound than it initially appears. First, support for the Zelaya Government reflected an unusual alignment of interests. Governments that typically oppose intervention on principle, and have reason to fear it in practice (such as the governments of Cuba, Venezuela, and Nicaragua) happened also to be governments politically aligned with Zelaya, whereas many governments unfavourably disposed toward Zelaya (such as that of the United States) had committed themselves to a vision of the international rule of law that obliged them at least to pay lip service to demands for Zelaya's restoration. The latter group could be assured that the rhetorical posturing in this case would be unable to achieve Zelaya's restoration, while it is hardly clear that the former group would be willing to live with the implications of its legal position as applied to other political circumstances. ${ }^{169}$ Moreover, sitting governments, regardless of their constitutional or ideological basis, tend to be easily recruited to join in a political condemnation of a fellow government's

167 United States Constitution art VI $\S 1 \mathrm{cl} 2$.

168 Ginger Thompson and Marc Lacey, 'OAS Votes to Suspend Honduras Over Coup', New York Times (New York), 4 July 2009.

169 Zelaya's strongest intemational backers - Presidents Hugo Chavez of Venezuela and Daniel Ortega of Nicaragua - have repeatedly faced objections to the constitutional propriety of their modes of governance. For example, Venezuela's 1999 constitutional revision, though accomplished with strong popular support, was accompanied by significant breaches of the then-existing constitutional order. See Larry Rohter, 'Venezuelan Congress Fights Loss of Power', The New York Times (online), 27 August 1999 <http://www.nytimes.com/1999/08/27/world/ venezuelan-congress-fights-loss-of-power.html>. 
irregular ouster. It is hard to know what the unanimous assent to Resolution 63/301 says about the opinio juris of Cuba, one of the resolution's sponsors, let alone of Russia, China, Saudi Arabia, Myanmar, Sudan, and so on.

Second, the Honduras crisis had a near-term expiration date. Zelaya's term was coming to an end in January 2010, at which point all constitutionally-grounded claims on his behalf would dissipate. The new government of President Porfirio Lobo, deriving from October 2009 elections that were not seriously marred by irregularities and boycotts, faced problems in its diplomatic re-incorporation into the international system, but it did not face an internationally recognised government-in-exile that could call into question its legal capacities.

It is instructive that while the Honduran coup regime's leader was barred from addressing the opening of the UN General Assembly's 2009 session, top officials of no less than twelve coup-installed governments did address that body - presided over, ironically, by the representative of Libya's 40 -year coup-installed regime. ${ }^{170}$ Apart from Micheletti, the only de facto leader denied permission to address the General Assembly was Malagasy President Andry Rajoelina, whom the military had installed after ousting elected President Marc Ravalomanana in March 2009. Both the AU and the Southern African Development Community had suspended Madagascar as a result of the interruption in constitutional rule. Although Rajoelina was not permitted to address the UN General Assembly, the Credentials Committee neither accepted nor rejected the credentials of his government's representatives to the General Assembly, thereby provisionally permitting those representatives to participate in the work of UN bodies (the same solution as applied to representatives of Guinea's coup regime). ${ }^{171}$ After a year of fruitless efforts to negotiate the Rajoelina govemment's relinquishment of power, the AU in March 2010 imposed extensive sanctions on Madagascar's de facto leaders (including travel bans and asset freezes), and urged other intergovernmental organisations to impose further diplomatic isolation. ${ }^{172}$ Thus far, however, there has been no assertion of the existence of an alternative government with the authority to represent Madagascar.

The international reactions to the Honduran and Malagasy coups, against the backdrop of respective regional instruments hostile to unconstitutional changes of government, demonstrate the growing discomfort with a blanket conferral of international standing on whatever regime establishes effective control through internal processes. Yet these reactions remain equivocal. The international system's continuing diversity of interests and values, let alone regime types, significantly impedes so fundamental a change in international legal relations as the systematic denial to coup regimes of the legal capacity to assert rights, incur

170 Patrick Goodenough, 'Regimes Arising from Coups Should Be Barred from UN Institutions, African Official Says', CNSNews.com (online), 29 September 2009 <http://www.cnsnews.com/news/print/54694>: Goodenough lists Burkina Faso, Burma, Central African Republic, Equatorial Guinea, Fiji, The Gambia, Guinea, Libya, Oman, Qatar, Sudan and Tunisia as coup regimes represented among the speakers.

171 Report of the Credentials Committee, UN GAOR, $64^{\mathrm{th}}$ sess, UN Doc A/64/571 (17 December 2009) [11].

172 'Madagascar: Will AU Sanctions Be a "Wake-Up Call"?', Integrated Regional Information Networks (online), 18 March $2010<$ http://www.irinnews.org>. 
obligations, exercise powers, and confer immunities on behalf of their states in the international order.

\section{Conclusion: THE DECLINE OF THE EFFECTIVE CONTROL DOCTRINE AND THE ABSENCE OF A COHERENT SUBSTITUTE}

The effective control doctrine that, in different forms, has governed the recognition of states and governments is unappealing at its core. Based on the principle of non-interference in civil strife within established international borders, the doctrine's essential logic is that, in regard to internal efforts to create new states by secession or to overthrow existing constitutional orders, the international rule of law reduces to respect for the outcomes of trials by ordeal. Traditionally, international law has not established any pathway by which secession can be peacefully achieved without the consent of the original state, nor has it systematically predicated a governmental apparatus' standing to exercise the state's legal prerogatives on anything other than victory in an internal power struggle. In these fundamental ways, international law has seemed to lack a 'rule of law' character.

Nonetheless, alternatives are elusive, and not merely because of realpolitik considerations. Appeals to the idea of 'popular' rather than 'state' sovereignty miss the point that opposing sides in an internal conflict typically claim this mantle. The right of peoples to self-determination is associated with non-fragmentation as much as with independence; respect for majority rule presupposes an answer to the very question being contested - the 'majority of whom?' problem - and respect for minority rights presupposes straightforward resolutions to clashes, not only between legitimate majority and minority interests, but also between minorities and minorities-within-minorities, between territorially concentrated and dispersed minorities, and between 'national' and 'non-autochthonous' minorities. Substantial sectors of the international community have an interest in avoiding the establishment of general principles that, while aiding in the solution of one crisis, will tend to destabilise local arrangements elsewhere.

Demands that local conflicts be resolved in accordance with existing domestic constitutional norms may seem to befit an international rule of law, but these demands misleadingly portray international and domestic legality as a seamless web. The international legal order as we have known it - as reflected in the language of such documents as the OAS Charter, the Friendly Relations Declaration, and the ICJ Nicaragua decision - is properly understood not as a legal order of legal orders, but as a legal order of sovereign political communities that each bear an 'inalienable' pouvoir constituant. That pouvoir constituant logically includes an authority (insofar as its exercise is deemed authentically attributable to its bearer) to overthrow any existing domestic order by any means.

While constitutionalism - a commitment to establish, maintain, and respect a broadly acknowledged framework for the legitimate exercise of power - is undoubtedly a crucial political virtue, the same cannot automatically be said for adherence to any particular constitutional norm or even the whole constitution. Existing constitutions are artefacts of past power struggles and negotiated settlements, and may preclude outcomes that are more consistent with popular 
will or with the protection of vital interests and rights of particular sectors. ${ }^{173}$ It is hard to see why a particular constitutional formula to which a substantial constituency militantly objects should, purely by virtue of its having been established, have a claim to international reinforcement.

Moreover, while democratic practice cannot be sustained for any length of time without a constitutionalist ethos, it does not follow that all departures from that ethos are inimical to democracy. What counts as a democratic outcome in any given instance is highly dependent on contested normative conceptions. From one perspective, in conditions of extreme economic disparity and social stratification, liberal-democratic constitutional forms are consistent with a substantive political inequality that belies the 'democratic' imprimatur; in the face of concentrations of economic and social power, a concentration of political power may be necessary to change the game. From another perspective, adherence to a particular constitutional formula may allow for demagoguery or deadlock to win the day at a critical historical moment, with potentially severe and lasting social costs. Where such assertions are facially plausible and are embraced by substantial constituencies, the words 'essentially within the domestic jurisdiction', expressing the principle of sovereign equality so central to the international legal order that we have lately known, seem apt.

That said, the existence of twilight does not refute the distinction between day and night. There remains an underlying moral logic to the international legal order, and the plurality of interpretations, while substantial, is not unlimited. A cross-cutting consensus in the international community is frequently achievable, if not about what popular sovereignty is, then about what it is not. Where the outcome of a local trial by ordeal is widely perceived to be in blatant contradiction to the notion of the state as embodying the self-determination of the entirety of the territorial population, or to the notion of the government as an authentic representative (for the time being) of the political community that the state encompasses, international institutions may repudiate that outcome and champion an alternative solution. That alternative solution, however, tends ineluctably to have an ad hoc character.

173 As Jean d'Aspremont notes, 'a coup d'état can prove to be a positive break from the existing order and can bring about a desirable change in regime', especially where an elected regime's mode of exercising power vitiates its initial legitimacy (emphasis altered): d'Aspremont, 'Responsibility for Coups d'État', above n 137, 473-4. 